University for Business and Technology in Kosovo

UBT Knowledge Center

Winter 1-2020

\title{
Auditimi i Sistemit të menaxhimit dhe vlerësimi i performancës në Kompaninë "Sole Kosova- Sh.p.k”
}

\author{
Bahtir Gashi \\ University for Business and Technology - UBT
}

Follow this and additional works at: https://knowledgecenter.ubt-uni.net/etd

Part of the Food Science Commons

\section{Recommended Citation}

Gashi, Bahtir, "Auditimi i Sistemit të menaxhimit dhe vlerësimi i performancës në Kompaninë "Sole Kosova- Sh.p.k"' (2020). Theses and Dissertations. 20.

https://knowledgecenter.ubt-uni.net/etd/20

This Thesis is brought to you for free and open access by the Student Work at UBT Knowledge Center. It has been accepted for inclusion in Theses and Dissertations by an authorized administrator of UBT Knowledge Center. For more information, please contact knowledge.center@ubt-uni.net. 


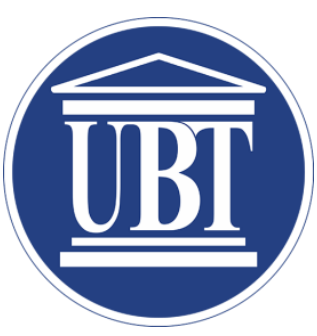

Kolegji UBT

Fakulteti i Shencave të Ushqimit dhe Bioteknologjisë

\section{AUDITIMI I SISTEMIT TË MENAXHIMIT DHE VLERËSIMI I PERFORMANCËS NË KOMPANINË “SOLE KOSOVA- SH.P.K”}

Shkalla Bachelor

Bahtir Gashi

Janar 2020

Prishtinë 


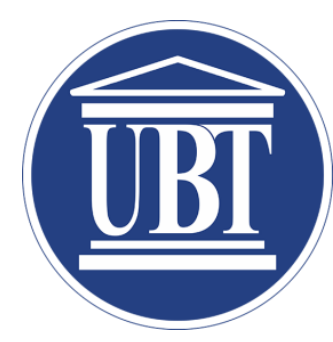

\title{
Kolegji UBT
}

Fakulteti i Shencave të Ushqimit dhe Bioteknologjisë

\section{Punim Diplome}

Viti akademik 2018/2019

\author{
Bahtir Gashi
}

\begin{abstract}
AUDITIMI I SISTEMIT TË MENAXHIMIT DHE VLERËSIMI I PERFORMANCËS NË KOMPANINË "SOLE KOSOVA- SH.P.K"

Mentori

Fisnik Laha
\end{abstract}

Muaji i dorëzimit/Viti i dorëzimit

Janar 2020

Ky punim është përpiluar dhe dorëzuar në përmbushjen e kërkesave të pjesëshme të shkallës

Bachelor 


\begin{abstract}
ABSTRAKT
Në këtë punim diplome është paraqitur auditim i isistemit të menaxhimit të cilësisë dhe sigurisë ushqimore në kompaninë "Sole-Kosova" SH.P.K

.Aspektet procedural të një auditimi të tillë janë realizuar kundrejt kritereve të kontrollit të cilat janë plotësisht brenda përshkrimeve në standardin ndërkombëtar të sistemit të menaxhimit dhe sigurisë ushqimore, EN ISO 22000. Qëllimi i punimit është vlerësimi i të gjitha procedurave kyçe perms një auditimi të brendshëm të sistemit të menaxhimit në kompani, procedura të cilat janë bazë për matjen e efektivitetit të po këtij sistemi. Vlerësimi i sistemit të tillë gjatë fazes së auditimit ka përfshirë, postjerash, edhe vlerësimin e adoptimeve të bëra në kompani në funksion të plotësimit të rekomandimeve për përmirësim të dala pas auditimeve periodike të sistemit të menaxhimit. Pas analizimit të tëgjeturave janë lënë rekomandimet shtesë për plotësime tjera teknike e procedurale, plotësime të cilat janë vlerësura si të nevojshme për rritjen e funksionalitetit të brendshëm operacional, duke pasur si orientim kyç rritjen e vazhdueshme të cilësisë në funksion të zbatimit të kritereve standard dhe plotësimit të vazhdueshëm të nevojave të klientëve.Auditimi i këtij sistemi ka rezultuar në ofrimin e një qasjeje të re dhe të pranueshme për menaxhmentin e lartë të kompanisë, qasje e cila është në funksion të mbajtjes së kostove optimal prodhuese kundrejt plotësimit të nevojave të vazhdueshme të tregut me produkte të sigurta dhe cilësore.
\end{abstract}

\title{
MIRËNJOHJE DHE FALEMINDERIME
}


Mirënjohje dhe falenderim për mentorin tim përn dihmën e pakursyer dhe sygjerimet e tij që kontribuan që ky punim të jetë sa më përmbajtësorë.

Një faleminderim i vecantë për familjen time që më kanë ndihmua rdhe përkrahur gjatë gjithë kohës së studimeve.

Njëkohësisht dëshiroj t'i falenderoj të gjithë ata që në mënyra të ndryshme më ndihmuan gjatë punimit të kësaj teme.

Përmbajtja 


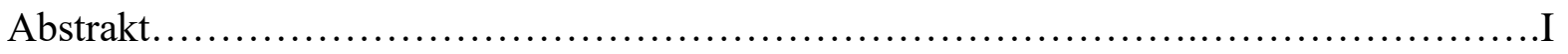

Mirënjohje dhe faleminderime................................................................

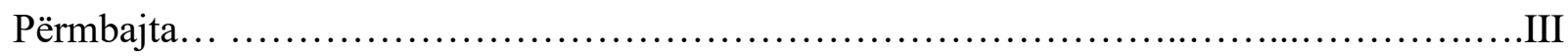

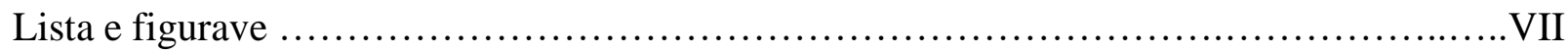

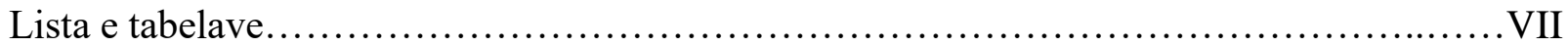

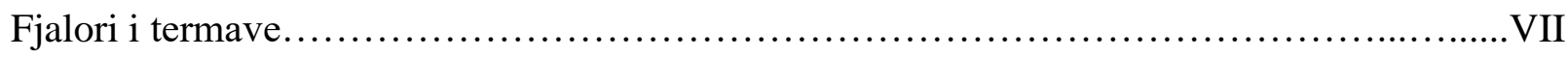

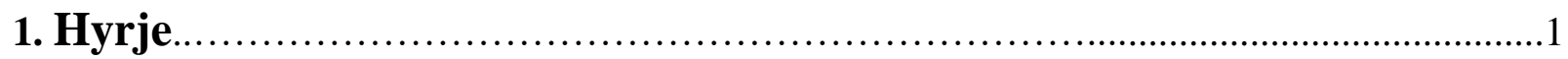

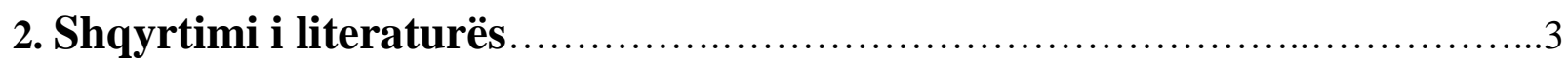

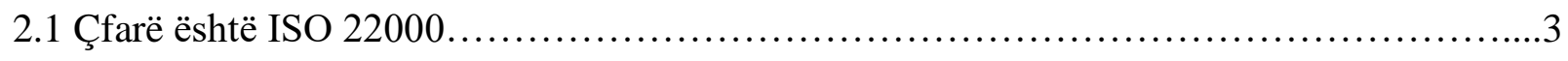

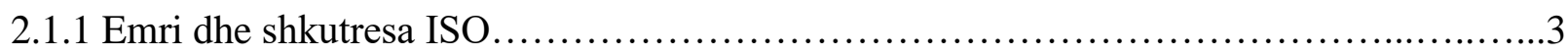

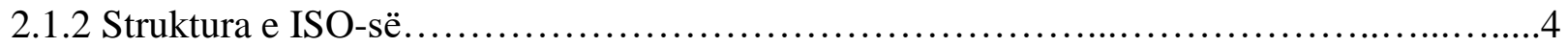

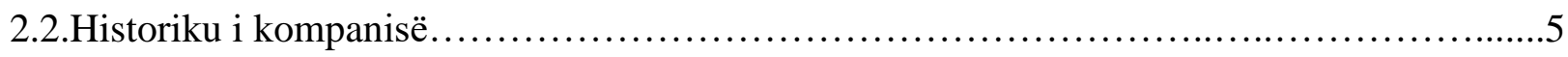

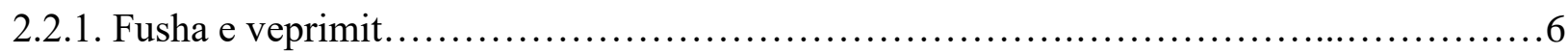

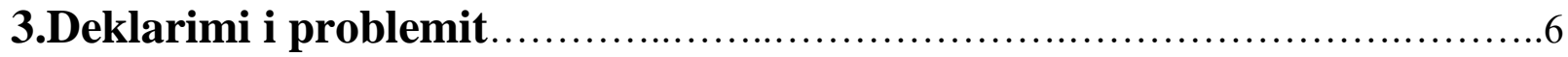

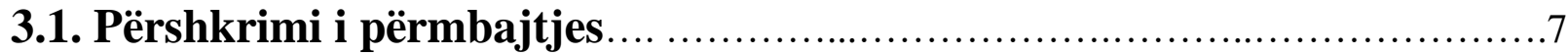

3.2. Qëllimi dhe fusha e aplikimit........................................................

3.2.1 Karakteristikat ................................................................... 10

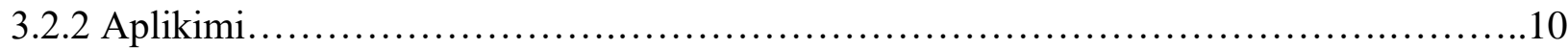

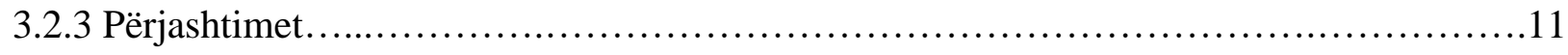

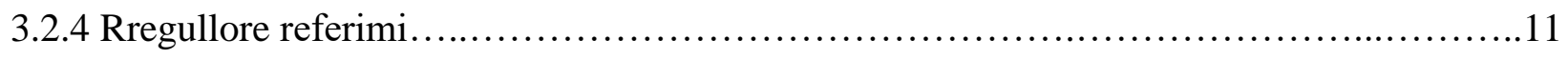

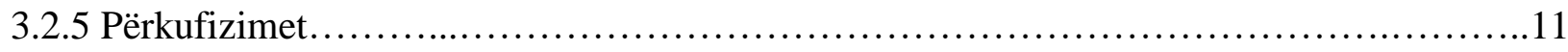

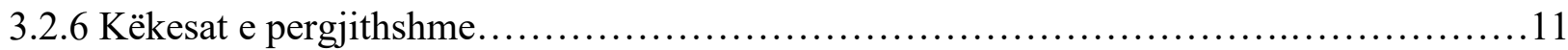

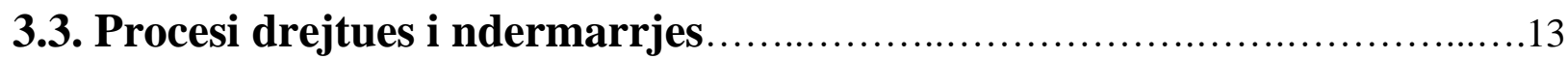

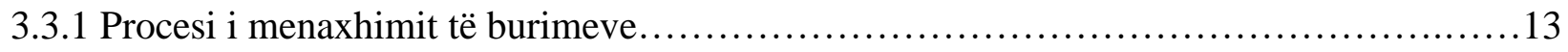

3.3.2 Procesi i menaxhimit të përmirësimeve ..........................................14

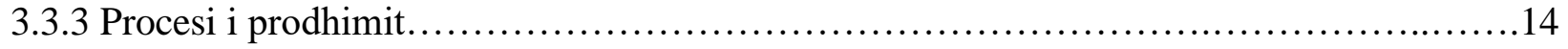

3.3.4 Kërkesat që lidhen me dokumentat............................................................................14

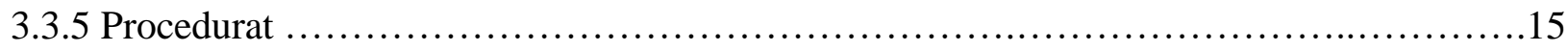

III

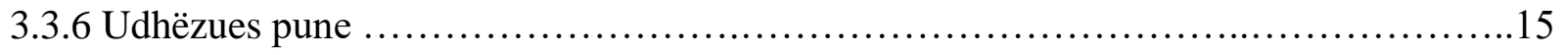




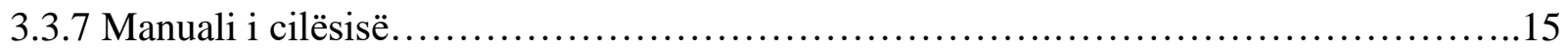

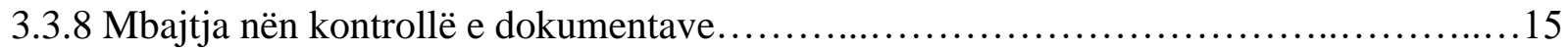

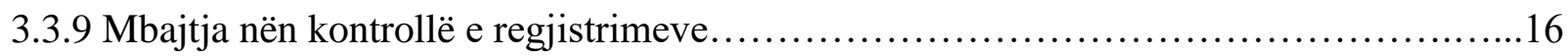

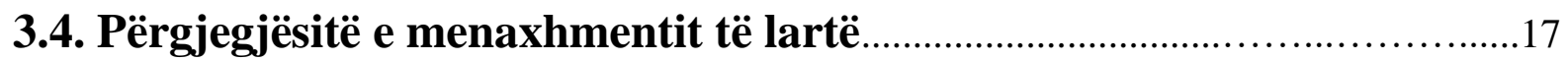

3.4.1 Kënaqësia e klientit........................................................... 17

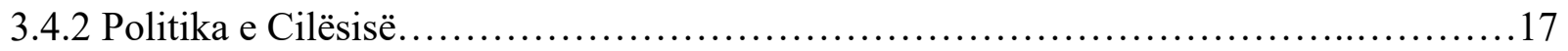

3.4.3 Objektivat e Cilësisë....................................................... 18

3.4.4 Planifikimi i sistemit të menaxhimit.......................................... 18

3.4.5 Diagrami rrjedhës i proceseve në kompani........................................... 19

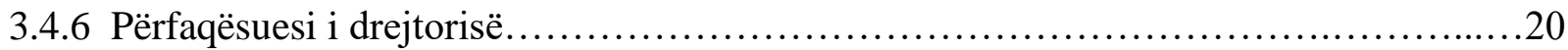

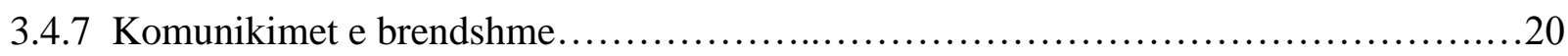

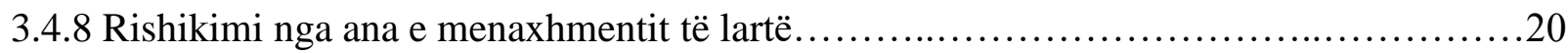

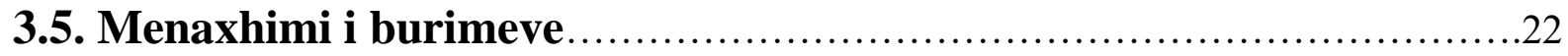

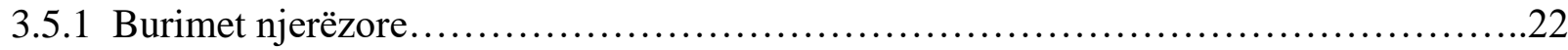

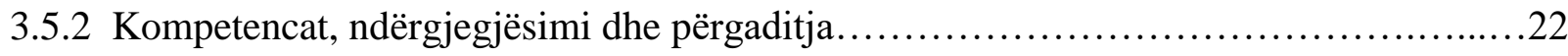

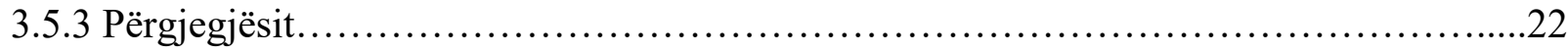

3.5.4 Menaxhimi i kompetencës ,ndërgjegjësimit dhe përgaditjes..........................22

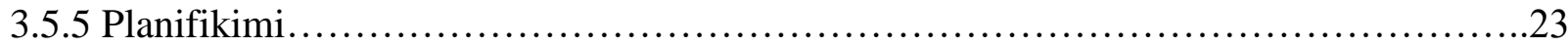

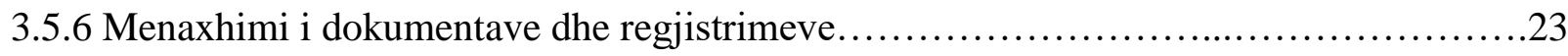

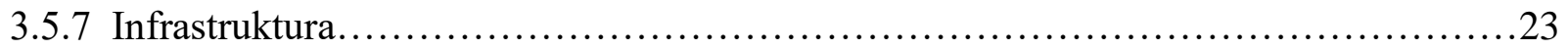

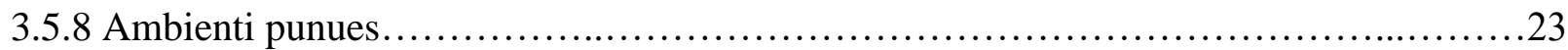

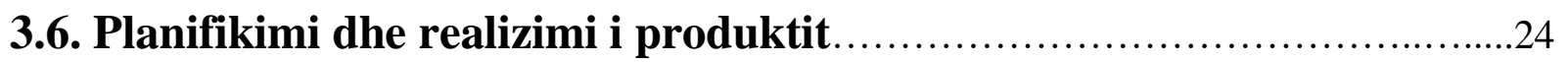

3.6.1 Proceset që lidhen me klientin -Përcaktimi i këkesave që lidhen me prodhimin............24

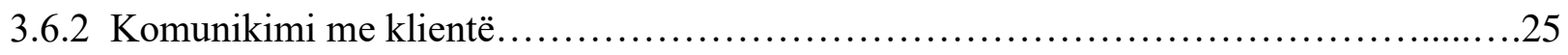

3.6.3 Projektimi dh ezhvillimi-Planifikimi i projektimit dhe zhvillimit........................25

3.6.4 Elementet fillestare në projektim, zhvillim dhe kontrolli i ndryshimeve...................26

3.6.5 Elementet përfundimtare që dalin nga projektimi dhe zhvillimi......................27

3.6.6 Rishikimi, verifikimi dhe vlefshmëria e projektimit dhe zhvillimit.......................27

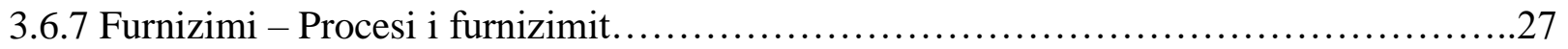




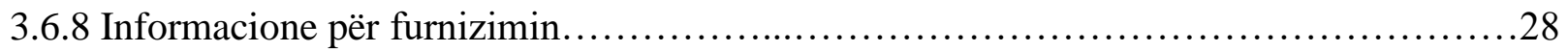

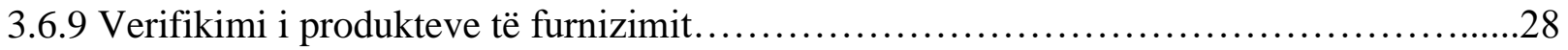

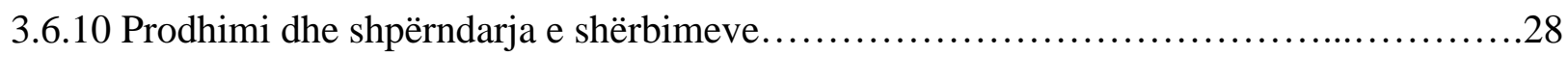

3.6.11 Vlefshmëria e proçeseve të prodhimit dhe shpërndarja e shërbimeve.......................29

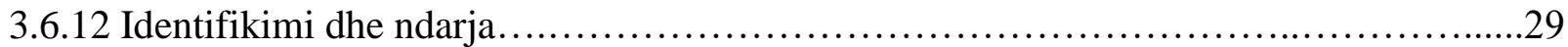

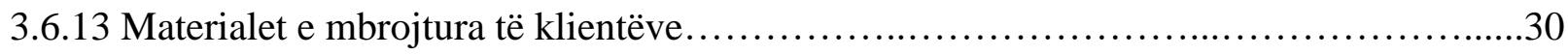

3.6.14 Kriteret e menaxhimit dhe regjistrimet e cilësisë.......................................30

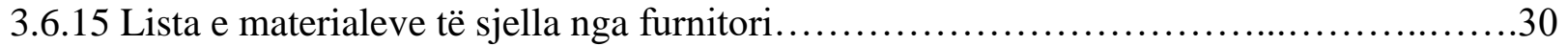

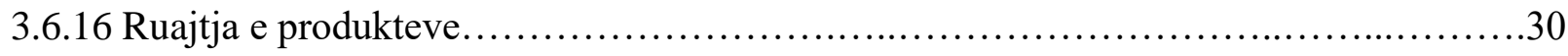

3.6.17 Mbajtja nën kontroll e monitorimeve dhe matjeve......................................31

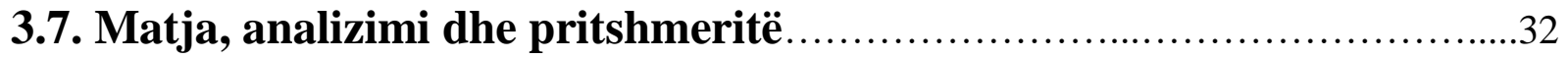

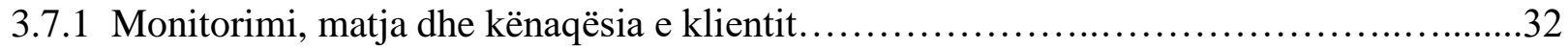

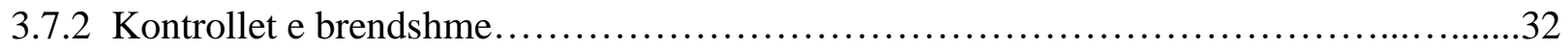

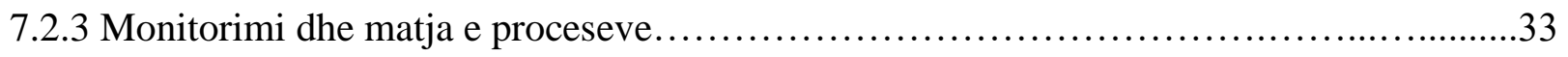

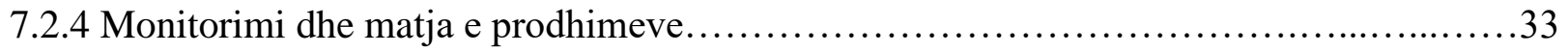

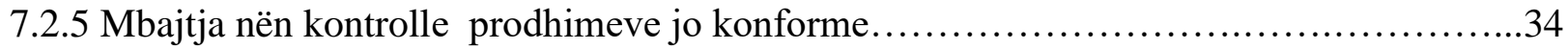

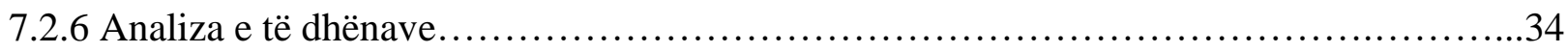

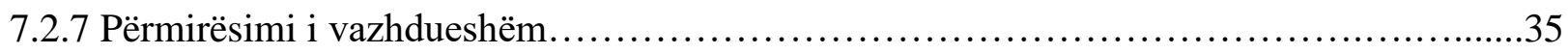

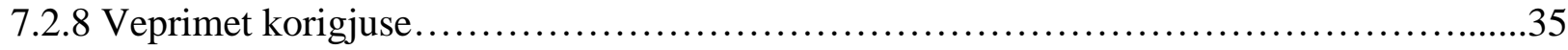

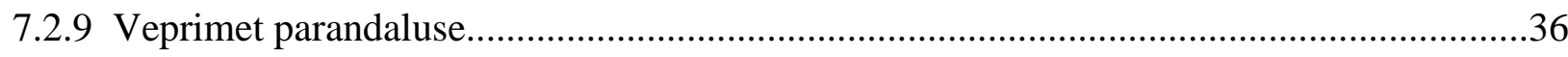

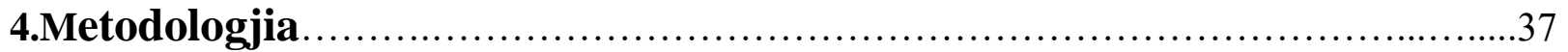

4.1 Procedura e auditimit të brendshëm - Qëllimi dhe objektivat...............................37

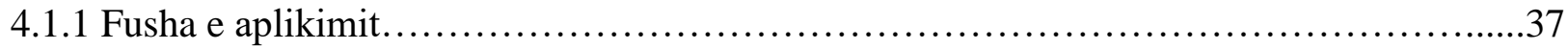

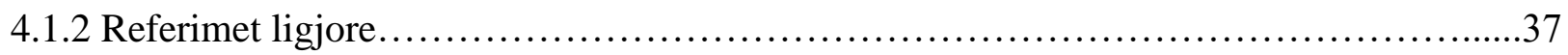

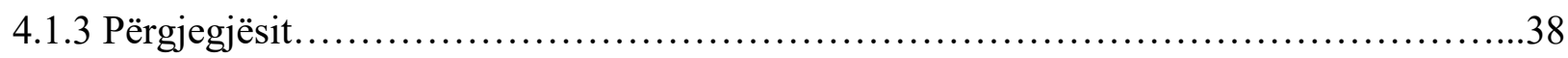

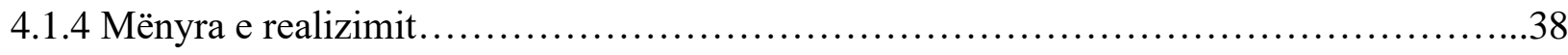

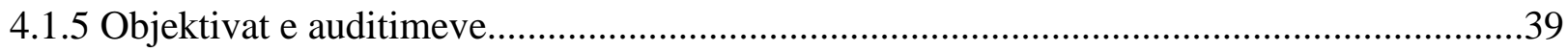

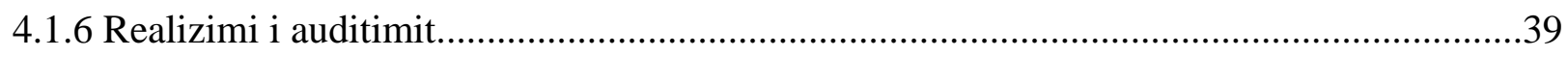

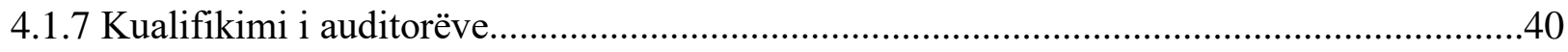

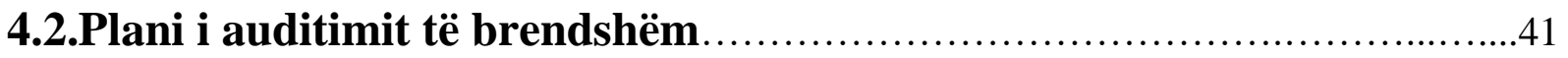


4.2.1 Raporti i të gjeturave nga auditimi i brendshëm..................................44

5. Prezentimi dhe analiza e rezultateve......................................54

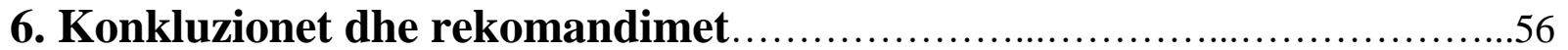

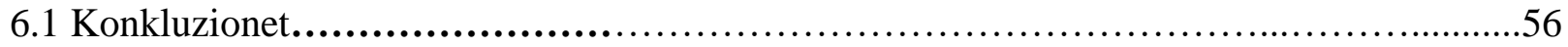

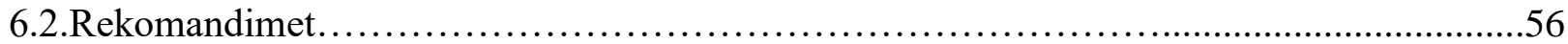

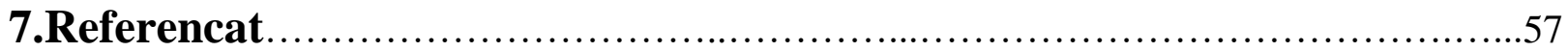


Foto 1.Vendodhja e kompanisë.

\section{LISTA E TABELAVE}

Tabela 1.Kerëkesat e përgjithshme. 12

Tabela 2. Diagrami rrjedhës i proceseve në kompani........................................19

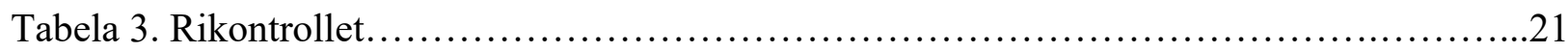

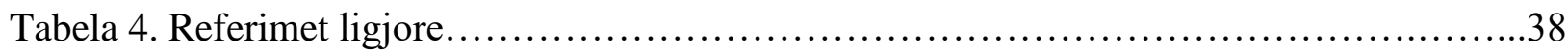

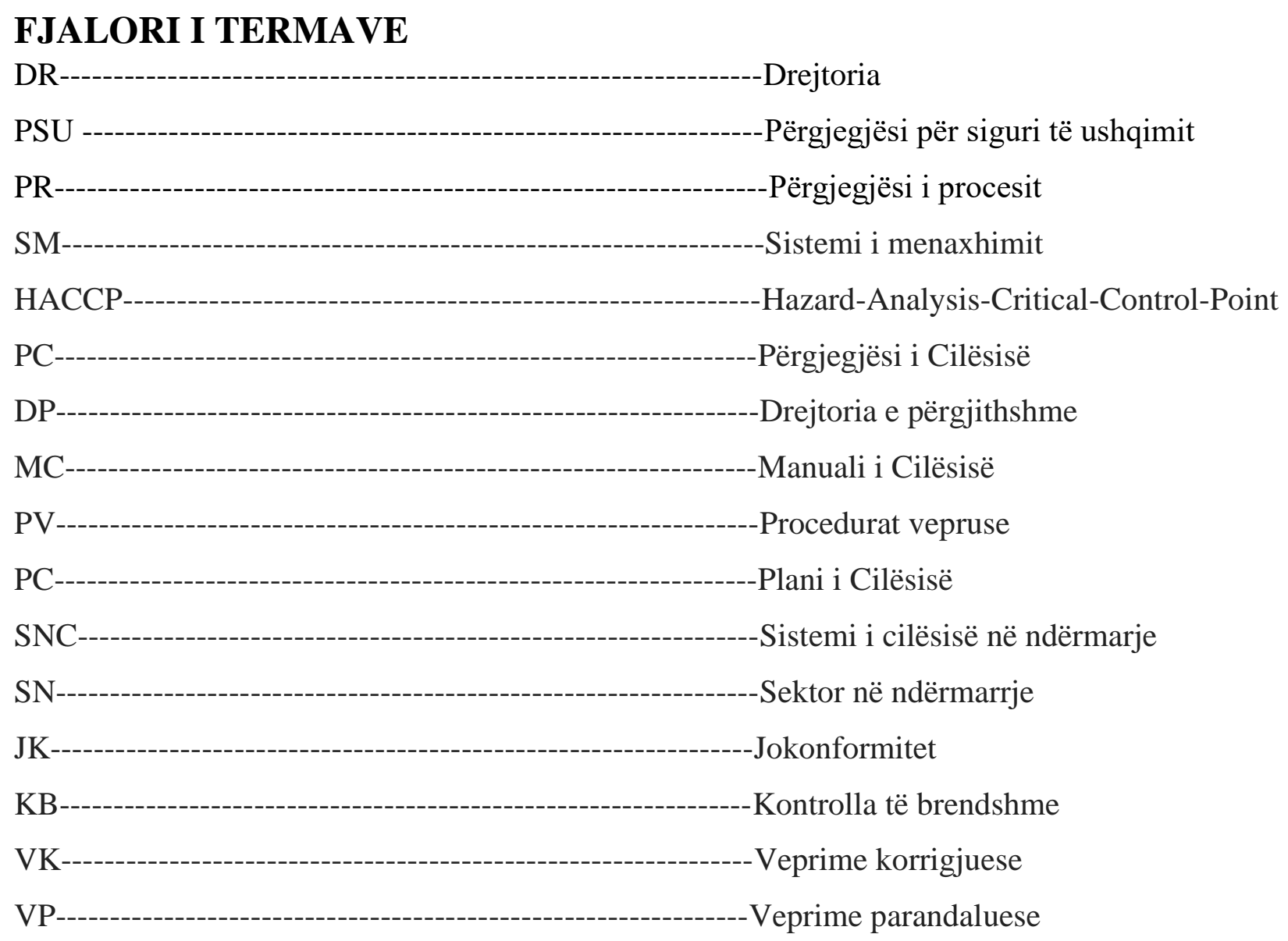




\section{Hyrje}

Auditimi si proces, mbeshtetet në një numër të caktuar të parimeve. Këto parime ndihmojnë që auditmin ta bëjnë një vegël me efektive dhe më të besueshme në mbeshtetje të menaxhimit dhe kontrollit të politikave, duke ofruar informacion mbi të cilin organizata mbështet veprimet e saja, në mënyre që të përmiresoj performancen e sistemit. Zbatimi i këtyre parimeve ka shërbyer si një premisë per ofrimin e konkluzioneve te auditimit te cilat jane relevante dhe te mjaftueshme, duke bërë të mundur që auditimi të reflektoj në përpikëri të gjeturat si dhe të arrijë të identifikoj mundësitë për përmirësim.Në mënyrë që të kuptohet konteksti i këtij auditimi, programi i auditimit ka marrë në konsideratë këto karakteristika të të audituarit:Objektivat organizative, problemet relevante të brendshme dhe të jashtme, nevojat dhe pritshmëritë e grupeve relevante të interesuara, kërkesat për siguri dhe konfidencialitet të informacionit.

Në mënyrë që të ofrohet siguria e ushqimit përgjatë zinxhirit ushqimor është e domosdoshme implementimi i kritereve të bazuara në ISO 22000:2018 për sigurimin e kushteve higjienike për prodhimin e ushqimit të shëndetshëm(higjiena e personelit,higjiena e pajisjeve, higjiena e lëndës së parë, higjinea e mjedisit,higjiena e përgjithshme,etj).

Zbatimi i standardit në të gjithë zinxhirin ushqimor, rritja e garancisë në sigurinë e produkteve, dokumentimi i sigurisë ushqimore, parandalimi në vend të korrigjimit, eficienca në kontrollin e kostove, zvogëlimi i sasisë së produkteve që janë pa specifikime, zhvillimi i dokumentacioneve për përputhshmërinë ligjore, përdorimi më i mirë i burimeve, përmirësimi i imazhit të kompanisë si dhe promovimi i tregëtisë së shëndetshme në nivel ndërkombëtar, janë vetëm disa nga përfitimet e aplikimit të kritereve të standardit ISO 22000:2018. 


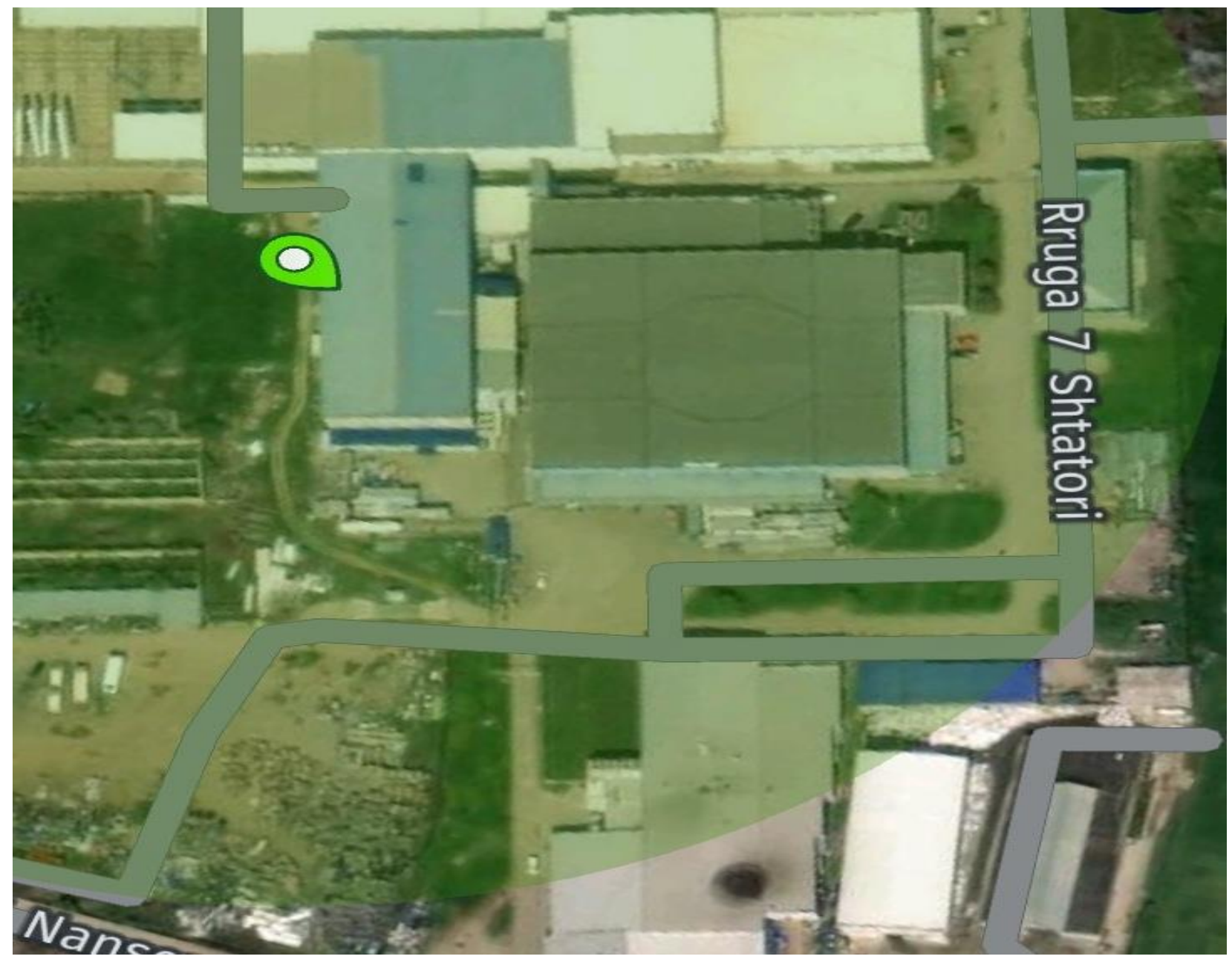

Foto 1. Vendodhja e kompanisë Sole-Kosova SH.P.K- Fushë-Kosovë 


\section{Shqyrtimi i literaturës}

\subsection{Standardet e sistemit të menaxhimit të sigurisë ushqimore}

Standardet e sistemit të menaxhimit në industrinë ushqimore janë standarde ndërkombëtare të krijuara për të siguruar zinxhir të furnizimit me ushqime të sigurta në të gjithë botën,duke lejuar organizatat të demostrojnë aftësinë e tyre për të kontrolluar rreziqet e sigurisë ushqimore dhe të sigurojnë që ushqimi të jetë i sigurtë për konsum njerëzor.Standardi ISO 22000:2018 është i zbatueshëm për të gjitha organizatat e çdo madhësie,brenda zinxhirit ushqimor, dhe njihet në të gjithë botën nga palët e interesuara, siç janë autoritetet rregullator, prodhuesit, përpunuesit, paketuesit e ushqimit, shitësit me pakicë dhe konsumatorët.

\subsubsection{Emri dhe shkutresa ISO}

Gjuhet zyrtare të standardeve ISO janë: Gjuha angleze, gjuha frënge dhe gjuha ruse. Pasi që organizata përdorte akronime të ndryshme ne gjuhë të ndryshme si: ISO në gjuhën angleze, OIN në gjuhë frënge dhe përmes kësaj erdhi deri të miratimi me emrin ISO, bazuar në fjalët greke 'isos' që do të thotë 'të barabartë'. Emri ISO dhe logo e saj janë dy marka të regjistruara dhe përdorimi i tyre është i kufizuar.

\section{Historiku}

Organizata, sot e njohur si ISO,filloi punën në vitin 1926 si Institucion Ndërkombëtar i Shoqatave Kombëtare për Standartizim(ISA). ISA u pezullua nga viti 1942 por me vonë u afrua nga Komiteti Kordinues i Standarteve, i formuara kohëve të fundit nga Kombet e Bashkura,UNESCC, me një propozim për të formuar një trup të ri të standarteve globale.Në tetor të vitit 1946 delegatë nga 25 vende u takuan në Londër dhe ranë dakord që të bashkohen për të krijuar Organizaten e re Ndërkombëtare për Standardizim.Kjo organizatë zyrtarisht filloi punën në shkurt të vitit 1947

\subsubsection{Struktura e ISO-së}


ISO është një organizatë vullnetare e standardizimit, anëtarët e së cilës janë autoritetet të cilat përfaqësojnë vendet korrespondente.

Anëtarët e organizates takohen çdo vit në Asamblenë e Përgjithshme pë të diskutuar objektivat strategjike të ISO-së. Ndërsa përgjegjës për me shumë se 250 komitete teknike,të cilat zhvillojnë standardet ISO, është bordi teknik menaxherial. ISO ka 164 anëtarë kombëtar dhe përfshinë tri kategori të antarësimit:

I. Organet anëtare - janë organet kombëtare që konsiderohen si organi më përfaqësues i standartizimit në çdo vend.Këta janë të vetmit anëtar të ISO-së që kanë të drejtë vote.

II. Anëtarët korrospondent - janë vendet që nuk e kanë të drejtën e organizimit të ketyre standarteve.Këta antarë janë të informuar vetëm në lidhje me punën e ISO-ve.

III. Anëtarët parapagues - janë vende me ekonomi të vogla,këta paguajnë tarifa të reduktura për anëtarsim, por mund të ndjekin edhe zhvillimin e standarteve.

\subsection{Historiku i kompanisë}


"Sole- Kosova" është një emër tashmë i njohur në të gjithë Kosoven. Kompania, e cila është pasardhëse e kompanisë "Koral”, ka nisur aktivitetin e saj në vitin 1991. Është një nga liderët në fushën e ofrimit të artikujve ushqimorë në tregun e Republikës së Kosovës dhe më gjerë.Bashkëpunimi me kompani prestigjioze ndërkombëtare, importimi prej tyre i produkteve më cilësore dhe plasimi i tyre në treg, e kanë bërë këtë kompani të njohur, të dashur dhe të pranuar për konsumatorët vendorë. Duke pasur si synim parësor cilësinë, sigurinë dhe shëndetin, "Sole Kosova" po zgjeron dita ditës veprimtarinë e saj, po shton numrin e të punësuarëve, po rrit numrin e produkteve dhe po e përsosë në vijimësi punën e vet prodhuese. Qëllimi i vetëm i kësaj qasje është që konsumatori, përdoruesi i produkteve të kësaj kompanie, të jetë plotësisht i kënaqur dhe të jetë pjesë e kompanisë, sikurse deri më tash.

Në kuadër të kompanisë funksionojnë:

\section{- $\quad$ Fabrika për përpunimin e produkteve të mishit në Fushë-Kosovë;}

- $\quad$ Fabrika për përpunimin e produkteve të pemëve dhe perimeve në Fushë-Kosovë;

Fabrika për përpunimin e produkteve të mishit ndodhet në zonen industriale të Fushë Kosovës. Ajo ka një sipërfaqe prej $7000 \mathrm{~m}^{2}$.Ndërrmarja IMF Sole- Koral është një nga ndërrmarjet e cila ka një histori të gjatë në biznesin e përpunimit të mishit dhe të lëndeve të para të industrisë së prodhimit të sallameve dhe proshutave. Mbështetur në një eksperiencë mjaft të pasur, veçanërisht në drejtim të teknologjise së prodhimit të produkteve të përpunuara të mishit, në vitin 2008 nderrmarja vendosi të investojë më tej në këtë drejtim duke përmirësuar ambientet e saj sipas standardeve europiane. Tashmë ndërrmarja ka një shtrirje mjaft të gjerë dhe mund të thuhet se IMF Sole- Koral është një lider në treg dhe një markë në nivel kombëtar. Për arritjen e këtij objektivi nga ana e kompanisë janë bërë investime shumë të rëndësishme për ndërtimin e një kapaciteti prodhues që plotëson parametrat e standardeve ndërkombëtare si dhe ka vënë në përdorim pajisje dhe tekonologji nga më të avancuarat e kohës.

Veçanërisht investimi i ndërmarrjes është fokusuar në përmirësimin esencial të cilësisë së produkteve si dhe të cilësisë dhe efektivitetit të menaxhimit, si nje parakusht për një fushatë intensive që do të pasojë zgjerimin e tregut të ndërrmarjes.

\subsubsection{Fusha e veprimit}


Kompania ka një fushë të gjerë të veprimit, kryesisht merret më përpunimin e produkteve të mishit,frutave dhe perimeve e gjithashtu dhe me prodhimin e majonezit, keqapit dhe salcave të ndryshme, tregtia me shumicë e produkteve të qumështit, vezëve, vajrave dhe yndyrnave të gatimit, tregtia me pakicë e mishit dhe produkteve të mishit në dyqane të specializuara, tregtia me shumicë e mishit dhe produkteve të tij, magazinimi dhe ruajtja e produkteve ushqimore, transporti rrugor i mallrave.

\section{Deklarimii problemit}

Kjo tematikë e hulumtimit specifikon kërkesat për një sistem të menaxhimit të sigurisë ushqimore (SMS) për t'ia mundësuar kompanisë 'Sole Kosova":

a) Të planifikoj, zbatoj, funksionalizoj, mirëmbajë dhe rishikoj një SMC duke siguruar produkte dhe shërbime që janë të sigurta,në përputhje me përdorimin e tyre të synuar;

b) Të demonstrojnë pajtueshmërinë me kërkesat e zbatueshme ligjore dhe rregullatore të sigurisë së ushqimit;

c) Të vlerësojnë kërkesat e sigurisë së ushqimit të klientit dhe të demonstrojë konformitetin më klient;

d) Të komunikojnë në mënyrë efektive çështjet e sigurisë ushqimore për të interesuarit dhe palët brenda zingjirit ushqimor;

e) Të siguroj që organizata të përputhet me politikën e saj të deklaruar të sigurisë ushqimore;

f) Të demonstroj përputhshmëri me palët përkatëse te interesuara;

g) Të kërkojë certifikim ose regjistrim të SMS-së së tij nga një organizatë e jashtme, ose të bëjë një vetëvlerësim ose vetëdeklarim i konformitetit përkitazi me kërkesat e kësaj qasjeje.

Të gjitha kërkesat e këtij punimi kanë për qëllim të jenë të zbatueshme për kompaninë “SoleKosova"

\subsection{Përshkrimi i përmbajtjes}




\section{Qëllimi dhe fusha e aplikimit}

1.1 Qëllimi

1.2 Prezantimi i ndërmarrjes

1.2.1 Karakteristikat

1.2.2 Pasqyra e aktiviteteve

1.3 Fusha e aplikimit

2.Rregullorja e referimeve

3.Përkufizime

3.1 Fjalori

3.2 Lidhja me EN ISO 9001

3.3 Shkurtimet

4.Sistemet e administrimit për cilësinë

4.1 Kushtet e nëvojshme

4.2 Kushtet e lidhura me dokumentacionin

4.2.1 Karakteristikat

4.2.2 Manuali i cilësisië

4.2.3 Mbajtja nën kontroll e dokumenteve

4.2.4 Mbajtja nën kontroll e regjistrimeve

5.Përgjegjësitë e drejtorisë

5.1 Përkushtimi i drejtorisë

5.2 Kujdesi i përqëndruar tek klienti

5.3 Politika e cilësinë

5.4 Planifikimi

5.4.1 Objektivat e cilësinë

5.4.2 Planifikimi i sistemit të menaxhimit të cilësisë 
5.5 Përgjegjësia, autoriteti dhe komunikimi

5.5.1 Pëgjegjësia dhe autoriteti

5.5.2 Përfaqësuesi i drejtorisë

5.5.3 Komunikimi i brendshëm

5.6. Rikontrollimi nga ana e drejtorisë / karakteristikat

5.6.1 Detajet e futura për rikontrollim/elementet që dalin nga rikontrolli

\section{Administrimi i burimeve}

6.1 Vënia në dispozicion e burimeve

6.2 Burimet njerëzore

6.2.1 Karakteristikat

6.2.2 Kompetenca, ndërgjegjesimi dhe të ushtruarit e funksionit

6.3 Infrastruktura e ambientit të punës

\section{Realizimi i prodhimit}

7.1 Planifikimi i realizimit të prodhimit

7.2 Proceset në lidhje me klientin

7.2.1Përcaktimi i kushteve të domosdoshme të lidhura më prodhimin

7.2.2 Rikontrollimi i kushteve të domosdoshme të lidhura më prodhimin

7.2.3 Komunikimi me klient

7.3 Projektimi dhe zhvillimi

7.4 Furnizimet

7.4.1 Procesi i furnizimit

7.4.2 Informacionet për furnizimin

7.4.3 Verifikimi i prodhimeve të furnizuesve

7.5 Prodhimi dhe shpërndarja e shërbimeve

7.5.1 Mbajtja nën kontroll e aktivitetit të prodhimit dhe të shpërndarjes së sherbimeve 
7.5.2 Vlefshmëria e proceseve të prodhimit dhe të shpërndarjes së sherbimeve

7.5.3Identifikimi dhe zbulimi

7.5.4 Patentat e klientit

7.5.5 Rujtja e prodhimeve

7.6 Mbajtja nën kontroll e udhëzuesve të vëzhgimit dhe matjeve

8.Matja, analizimi dhe përmirësimi

8.1 Karakteristikat

8.2 Vezhgimi dhe matja

8.2.1 Knaqësia e klientit

8.2.2 Kontrollet e brendshme

8.2.3 Vëzhgimi dhe matja e proceseve

8.2.4 Vëzhgimi dhe matja e prodhimit

8.3 Mbajtja nën kontrollë e produkteve jo konforme

8.4 Analiza e të dhënave

8.5 Përmirësimet

8.5.1 Përmirësimet e vazhdueshme

8.5.2 Veprimet korigjuese dhe parandaluese

\subsection{Qëllimi dhe fusha e aplikimit}




\subsubsection{Karakteristikat}

Qëllimi i këtij punimi është që t’i bëjë të ditur personelit të përfshirë në prodhim dhe distribuim rregullat, metodat, këshillat dhe normat, që të mund të vazhdojnë të ndjekin rregullat e përcaktuara nga sistemi i brendshëm i ndërmarrjes me qëllim që të realizojnë sa më mirë kërkesat e klientëve. "Sole-Kosova" SH.P.K përmes sistemit të menaxhimit të cilësisë është e detyruar të demostrojë aftësinë e saj për të furnizuar me rregullësi prodhimet që përputhen me kërkesat e klientëve dhe me kërkesat e detyrueshme për t’u aplikuar. Kompania dëshiron të rrisë kënaqësinë e klientit përmes realizimit efikas të sistemit,këtu përfshihen edhe proceset për përmirësimin e vazhdueshëm të sistemit të garancisë së përputhshmërisë në kushtet e vëna në kontratë.

\subsubsection{Aplikimi}

Ky dokument i konceptuar në përputhje me kërkesat standarde, përmbledhë të gjitha rregullat e menaxhimit që ndërmarrja i ka përcaktuar në të gjitha hapësirat dhe ndaj të cilave duhet t'u përmbahet i gjithë personeli. Çdo veprim që nuk i përmbahet përmbajtjes së manualit, duhet të jetë i kërkuar dhe i miratuar nga klienti dhe shprehimisht i pranuar nga drejtoria. Ky është rezultati i një bashkëpunimi të ngjeshur i të gjithë sektorëve të ndërrmarrjes, të mbështetur nga përgjegjësi i cilësisë i cili dokumenton mjetet dhe burimet metodologjike të përdorura nga ndërmarrja me qëllim përmirësimin e cilësisë së saj përmes përfshirjes dhe motivimit të të gjithë personelit. Ky dokument i drejtohet si furnizuesve, të cilët me propozimet e tyre mund të kontribuojnë në progresin cilësor të ndërmarrjes, ashtu edhe klientëve, në mënyrë të tillë që të ketë një orjentim për ndërmarrjen brenda së cilës do të realizohet prodhimi.

Sistemi i menaxhimit të cilësinë aplikohet në sektorin e tregtimit, përpunimit, magazinimit, paketimit dhe distribuimit të produkteve ushqimore.

\subsubsection{Përjashtime}


Përjashtohet pika 7.3 sepse nuk kryhet projektimi në kompani, sepse produktet e përpunura realizohen sipas recetave tradicionale dhe duke respektuar bazën ligjore në fuqi. Për produktet e tregtuar,kompania kryen blerjen e tyre dhe i shpërndan pa ndërhyrje mbi produktet.

\subsubsection{Rregullore referimi}

Gjatë përpilimit të kësaj teme mbi SMC-në në kompani u jemi referuar rregullave dhe direktivave të mëposhtme:

- $\quad$ EN ISO 9001/08 Sistemi i menaxhimit të cilësisë

- EN ISO 1911/15 Udhëzues për kontrollet e sistemeve të menaxhimit për cilësinë dhe menaxhimit të mjedisit

\subsubsection{Përkufizime}

Në këtë dokument janë të vlefshme përkufizimet e dhëna nga normat e referimit. Gjithashtu vlejnë përkufizimet e mëposhtme:

- Ndërmarrje / Organizatë :"Sole-Kosova” SHPK

- Klient: Konsumatori përfundimtarë, përdoruesi, blerësi, përfituesi.

\subsubsection{Këkesat e pergjithshme}

a. Të përcaktojë proceset e nevojshme për sistemin e menaxhimit të cilësisë dhe aplikimin e tyre në kuadër të organizimit;

b. Të stabilizojë vazhdimësinë dhe ndërveprimet mes proceseve;

c. Të fiksojë kriteret dhe metodat e nevojshme për te garantuar funksionimin efikas të proceseve;

d. Të garantojë disponueshmerinë e burimeve dhe informacioneve të nevojshme për të përballuar funksionimin dhe monitorimin e proceseve;

e. Të monitoroj,të masë dhe të analizoj proceset;

f. -Të aktualizojë veprimet e nevojshme për të arritur rezultatet e planifikura dhe përmirësimin e vazhdueshëm të proceseve.

Vazhdimësia dhe ndërveprimet mes këtyre proceseve, si dhe garantimi i burimeve dhe realizimi i rezultateve është përshkruar si më poshtë: 
Hyrjet:Sektorët /Rikontrolli i drejtorisë / Vlerësimi i burimeve

Daljet:Përmirësim i SMC-së / Përmirësim i shërbimeve / Ndarja e burimeve / Objektivat e përcaktuar të procesit

Dokumentat referues:Procesverbal i rikontrollit / Politika e cilësisë dhe objektivat

Objektivat: Të sigurohen burimet e nevojshme për menaxhimin e proceseve dhe menaxhimi i organizimit

Treguesit:Nr. i rikontrolleve të planifikuara

Ndërveprimet:Të gjithë proceset

Përgjegjësitë:Menaxhmenti i lartë

\subsubsection{Procesi i menaxhimit të burimeve}

Hyrjet:Veçimi i pajisjeve që kanë të bëjnë me prodhimin / kërkesat minimale për personelin / kërkesat e klientit / kërkesat e prodhimit dhe të klientit

Daljet:Planet e mirëmbajtjes / Planet e formimit / Kontratat e porositjeve / Porositjet e blerjes / Kontrolli i prodhimeve / Përcaktimi dhe zbulimi / Ruajtja e prodhimeve

Dokumentat referues:Dosjet e mirëmbajtjes dhe dosjet e nënpunësve

Objektivat:Mbjatja e pajisjeve efikase dhe të përshtatshme për procesin prodhues

-Të garantohet përgatitja dhe rishikimi i personelit

-Të garantohet përputhshmëria e prodhimeve të furnizimit dhe mbajtja nën kontroll e furnitorëve

-Të menaxhohet (të shpërndahen, të verifikohen dhe të miratohen) dokumentat në mënyrë të kontrolluar, të evitohet përdorimi i dokumentave të kaluara

Treguesit:Oraret e përgatitjes / Kostoja e punës / Shpenzimet për mirëmbajtjen e infrastrukturave / Shpenzimet për fuqizimin e infrastrukturave / Nr. i porosive mujore / Xhiroja rrjedhëse vjetore / Xhiroja vjetore para ardhëse/ Nr. i klientave të rinj / Nr. i jokonformoiteteve të furnizuesit / Nr. i veprimeve korrigjuese dhe nr. i veprimeve parandaluese

Ndërveprimet me:Të gjitha proceset

Përgjegjësitë:Zyra e financave, furnizuesit për cilësinë e produkteve dhe personelin

\subsubsection{Procesi i menaxhimit të përmirësimit}


Hyrjet:Rregjistrimet e procesit dhe të sistemit / Verifikimet inspektuese të brendshme

Daljet:Përpunim i të dhënave / Përputhshmëria e prodhimit / Veprimet korrigjuese dhe parandaluese

Dokumentat referues:Rikontrolli i drejtorisë

Objektivat :Të mbahen nën kontoll proceset dhe sherbimet si dhe përmirësimi i tyre

Tregusit :JK që kanë dalë/ Veprimet korrigjuese / Veprimet Parandaluese

Ndërveprimet:Të gjitha proceset

Përgjegjësi:Përgjegjësi i Cilësisë

\subsubsection{Procesi i prodhimit}

Hyrjet:Kërkesa e klientit / Receta e prodhimit

Daljet:Realizimi i prodhimit

Dokumentat referues:Udhëzuesi operativ, kapitulli 7

Objektivat:Procesi i prodhimit në përputhje me atë që është planifikuar dhe që prodhimi të kënaqë kërkesat e klientit

Tregusit :Nr. i JK gjatë fazës së prodhimit / Nr. i kontakteve

Ndërveprimet:Të gjithë sektorët

Përgjegjësi :Përgjegjësi i prodhimit dhe i cilësisë

\subsubsection{Kërkesat që lidhen me dokumentat}

Sistemi i menaxhimit të cilësinë, që është vënë në përdorim, përbëhet nga dokumentat e mëposhtëm:

1. Manuali i cilësisë;

2. Procedurat dhe udhëzuesit e punës;

3. Dokumentat për regjistrimin e cilësisë;

4. Lista e kërkesave (check lista) për kontrollet;

5.Dokumentat teknikë që përdoren për proceset specifike të shërbimit dhe për detyrimet ligjore.

\subsubsection{Procedurat}


Janë dokumenta në të cilët janë përshkruar kriteret për t'u ndjekur gjatë aktiviteteve menaxhuese përkatëse me qëllimin që të veprohet në përputhje me normat EN ISO 9001 si dhe të redaktuara në bashkëpunim me përgjegjësit e sektorëve të ndryshëm të paracaktuar të ndërmarrjes.

\subsubsection{Udhëzuesit e punës}

Janë dokumenta që shërbejnë për të detajuar informacionet mbi mënyrën e procedimit për të realizuar veprimet me karakter teknik ose praktik.Përpilimi i udhëzuesve të punës bëhet në bashkpunim të ngushtë me përgjegjësit e sektorëve të ndryshëm të paracaktuar të ndërmarrjes.

\subsubsection{Manuali i cilësisë}

Në lidhje me organizimin është paraqitur, aktualizuar, dokumentuar dhe rishikuar një manual i cilësisë në të cilin evidentohen:Fusha e aplikimit të sistemit të menaxhimit për cilësinë tek ndërmarrja, procedurat dhe ndërveprimet mes sektorëve të ndryshëm të ndërmarrjes përmes së cilave konkretizohen metodat të cilat ndërmarrja i përdor për të planifikuar dhe për të kontrolluar prodhimet dhe proceset e veta.

\subsubsection{Mbajtja nën kontroll e dokumentave}

Të gjitha veprimet që lidhen me veçimin, shpërndarjen, verifikimin, miratimin dhe ndryshimin e dokumentave të sistemit të cilësisë ose të regjistrimeve duhet të kryhen në mënyrë të kontrolluar. Gjithashtu edhe dokumentat që kanë të bëjnë me normat dhe ligjet e aplikuara, menaxhohen në mënyrë të kontrolluar dhe i përmbahen klasifikimeve që lidhen me ligjet apo normat e entit të shpërndarjes.

Dokumentat shpërndahen me një kodifikim të përcaktuar mirë. Për të gjetur dokumentin duhet:Titulli, kodi, data dhe treguesi i rishikimit

\subsubsection{Mbajtja nën kontrollë e regjistrimeve}


Rregjistrimet e cilësisë duhet të përpilohen dhe mblidhen nëpër të gjitha veprimet që kanë për qëllim cilësinë. Për të gjitha llojet e ndryshme të dokumentave të regjistrimit të cilësisë, që përdoren nga ndërmarrje, duhet të përcaktohen:

-veprimet referuese,

-sektori përgjegjës për ruajtjen,

-koha e ruajtjes,

-norma të cilës i referohen dhe ku dokumentacioni është i paraqitur.

Në lidhje me periudhat kohore të ruajtjes shfaqen rastet e mëposhtme:

\section{Dokument i përhershëm i regiistrimit të cilësisë}

-kur parashikohet një rishikim i vazhdueshëm i dokumentit (bëhet fjalë si për regjistra ashtu edhe për lista që paraqesin informacione përmbledhëse);

\section{Dokument i regjistrimit të cilësisë i lidhur me jetën profesionale}

-kur është e parashikuar mbledhja dhe ruajtja, pastaj rishikimi i dokumentave që lidhen me vlerësimin e një furnitori deri kur ato të vihen në përdorim.

Çdo dokument rregjistrues i cilësisë duhet t'i përgjigjet kërkesave të mëposhtme:

- të mbetet i lexueshëm

-i identifikueshëm

- i përcaktuar,

-të përmbajë të gjitha informacionet e kërkuara ose nga procedura të cilës i referohet ose nga metoda e paracaktuar

\subsection{Përgjegjësitë e menaxhmentit të lartë të ndërmarrjes}


Menaxhmenit i lartë duhet të mbajë me shumë rëndësi zbatimin e sistemit të menaxhimit të cilësisë, gjë e cila do të kontribuojë vendosmërisht në përcaktimin e seriozitetit, cilësisë dhe përputhshmërisë të aktivitetit të kompanisë në lidhje me klientat.

Kjo duhet të arrihet:

-Duke përcaktuar dhe shpallur politikën e cilësisë;

-Duke përcaktuar objektivat

-Duke siguruar gadishmërinë e mjeteve për arritjen e këtyre objektivave;

Gjithashtu menaxhmenti merr përsipër monitorimin e të gjithë sistemit të cilësisë përmes rikontrolleve periodike siç është e përcaktuar në sek. 5.6 të manualit të cilësisë.

\subsubsection{Kënaqësia e klientit}

Klienti përbën rolin më të rëndësishëm, për vetë faktin që përmes arritjes së përmbushjes të kërkesave të tij, i krijohen mundësitë ndërmarrjes që të fuqizohet dhe përhapet në treg.

Menaxhmenti për çdo porosi që duhet të kryejë dhe t'ja dorëzojë klientit, shton edhe direktiva të qarta për të përmirësuar kënaqësinë e vetë klientit:

-Duke përcaktuar kushtet e detyrueshme në lidhje me prodhimin:

-Duke monitoruar informacionet mbi përmbushjen e kërkesës së klientit duke e konsideruar si pikë matje për rendimentin e sistemit të cilësisë.

\subsubsection{Politika e Cilësisë}

Menaxhmenti, me një ritëm të përvitshëm dhe me rastin e " Rikontrollit të Drejtorisë " përcakton, rikontrollon dhe garanton që politika e cilësisë:

a) të jetë e përputhur me qëllimet e organizatës,

b) të jetë e bindur në arritjen e përmbushjes së kushteve të domosdoshme dhe të përmirësimit të vazhdueshëm të efikasitetit të sistemit të menaxhimit të cilësinë,

c) që të parashikojë një kuadër strukturor për të përcaktuar dhe rikontrolluar objektivat për cilësinë,

d) të komunikohet dhe të jetë e përfshirë në brendësi të organizatës,

e) të rikontrollohet për të qënë të bindur për përshtatshmërinë e saj të vazhdueshme.

\subsubsection{Objektivat e Cilësisë}


Të paktën një herë në vit,top menaxhmenti i lart i kompanisë, me rastin e rikontrollit të sistemit të menaxhimit të cilësisë verifikon që objektivat e cilësisë , të cilat janë paracaktuar, të jenë arritur në masën dhe sasinë e paracaktuar.

Në rastet kur objektivat nuk janë arritur në masën dhe sasinë e paracaktuar, si për arsye që varen nga veprimtaria e kompanisë ose për arsye të jashme nga vetë sipërmarrja, ndërmarrja merr përsipër përcaktimin e tyre në mënyrë sa më të përshtatshme. Për këto objektiva të reja, i jepet informacion të gjithë personelit të interesuar.

\subsubsection{Planifikimi i sistemit të menaxhimit të cilësisë}

Në planifikim, përveç fazave dhe aktiviteteve në të cilat mund të ndahet secili proces, një rëndësi të veçantë marrin:

-marrja e teknologjive të reja;

-bashkëngjitja e dokumentacionit teknik të makinerive;

-bashkëngjitja e dokumentacionit origjinal dhe në përputhje me mallin në hyrje;

-bashkëngjitja e të gjitha burimeve të nevojshme për përmbushjen e aktiviteteve;

\subsubsection{Diagrami rrjedhës i proceseve në kompani}




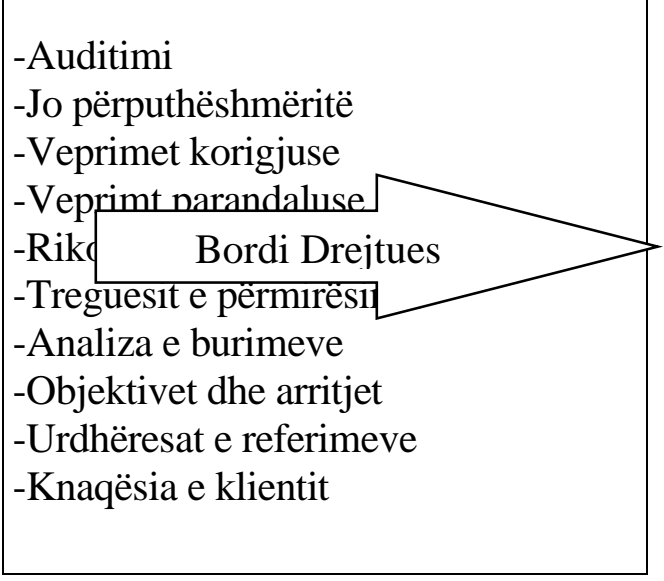

-Rikontrolli i drejtorisë -Statistikat

-Planifikimi i verifikimeve

-Plani i përmirësimit

-Menaxhimi i burimeve

-Planifikimi i rishikimit

-Kërkesat e klientit

-Përmbledhja e të dhënave të klientit

-Preventivat

-Mbi Financat

-Kushtere commosuosn

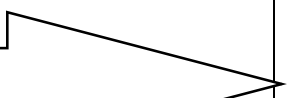

-Ofertat -kontratat

-Kushtet e përgjithëshme të shitjes

-Lista e ofertave

-Nisja e porosisë

-Kërkesë për blerje

-Teknika specifike

-Planifikimi i aktivitet -List $\quad$ Furnizimi

-Materraret

-Analizë tregu

-Kriteret e kontrollit të cilësisë

-Lista e furnitorëve

-Urdhëres për blerje

-Kontrolli i prodhimit

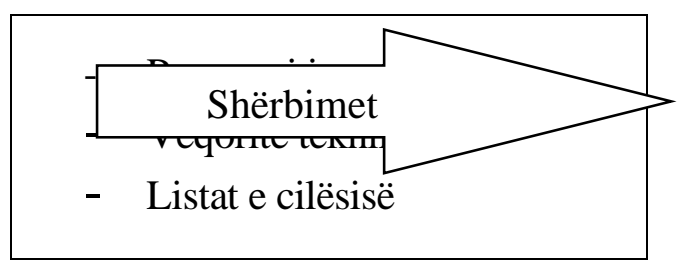

- Shërbimi i përfunduar

-Dokumentat e regjistrimit të cilësisë

-Dorëzimi

Tab.2 Diagrami rrjedhës i proceseve në kompani

\subsubsection{Përfaqësuesi i drejtorisë}


Përfaqësuesi i menaxhmentit të lartë është Përgjegjësi i Cilësisë i cili e zhvillon aktivitetin e tij me autoritet dhe në pavarësi të plotë, në shërbim për të garantuar që gjithëçka që përmbajnë dokumentet, të realizohen dhe mbahen nën kontroll.

\subsubsection{Komunikimet e brendshme}

Menaxhmenti, në bashkëpunim me përgjegjësit e departameneteve të ndryshme ka përcaktuar në lidhje me organizimin, përgjegjësitë që lidhen me gadishmërinë dhe mirëmbajtjen e nxjerrjes të të dhënave përbrenda sipërmarrjes.

\subsubsection{Rikontrollimi nga ana e menaxhmentit të lartë /elementet në hyrje dhe dalje}

Rikontrolli i

drejtorisë

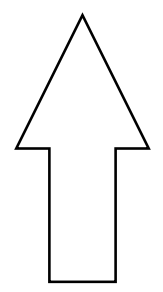

Fluks

informacionesh

\section{ELEMENTE NË HYRJE}

-Rezultatet e kontrollave të brendshme

-Informacione të kthyra nga klienti

-Niveli i projekteve

-Përputhja e produkteve

-Veprimet ndërhyrëse

-Veprimet parandaluse

-Rikontrollet e mëhershme

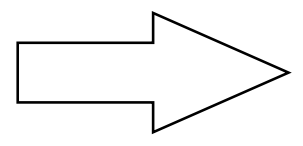

Analizë

shmangiesh

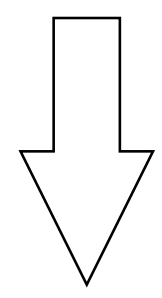

Programim i

rregullimeve dhe

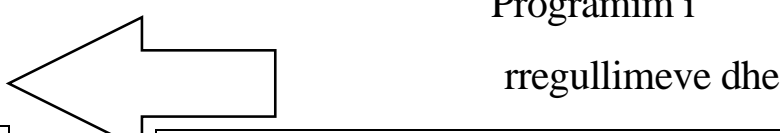

-Përmirësimi i efikasitetit të sistemittë

menaxhimit të cilësisë

-Përmirësimi i prodhimeve në përputhje me

kërkesat e klientve

-Financat 


\section{Tab. 3 - Rikontrollet}

Rikontrolli nga ana e menaxhmentit te lartë shërben për të shënuar pikën kyçe të zhvillimit të kompanisë për sa i përket cilësisë, duke raportuar shmangiet nga objektivat që kompania ka ndërmarrë përmes deklaratës së polikës të cilësisë dhe gjithashtu rezultatet reale të arritura nga tërësia e aktiviteteve të kompanisë.

Shpërndarja e dokumentit të rikontrollit të Cilësisë shoqërohet nga analiza e një sërë informacionesh të ardhura nga: rezultatet e nxjerra nga verifikimet inspektuese të brendshme, numri i gabimeve të bëra dhe prirja e tyre, numri i ankesave të klientëve dhe zgjidhja e tyre, zgjidhjet për problemet e cilësisë etj.

Ndërkohë nga rikontrolli i drejtorisë dalin: Përfundime, objektiva, strategji, burime të specifikuara, tregues të matshëm; 


\subsection{Menaxhimi i burimeve}

Menaxhmenti ka vënë në dispozicion burime të përshtatshme të seleksionuara herë pas here për:

-Të aktualizuar dhe rishikuar sistemin e cilësisë dhe për të përmirësuar në mënyrë të vazhdushme vlefshmërinë e tij;

-Për të rritur kënaqësinë e klientit

\subsubsection{Burimet njerëzore}

Kompania garanton gjithashtu që punonjësit, të cilët kanë funksione që ndikojnë tek menaxhimi i cilësisë dhe për punonjësit që s'kanë eksperiencë të mëparshme, të kalojnë një proces të përshtatshëm trajnimi duke punuar pranë përgjegjësve të reparteve ose afër ndonjë punonjësi i cili është specializuar në atë lloj aktiviteti.

\subsubsection{Kompetencat, ndërgjegjësimi dhe përgaditja}

Kompania merr përsipër të përcaktojë punonjësit e ngarkuar për aktivitetet e përgatitjes dhe të përshkruajë formalitetet dhe kriteret për përgatitjen dhe trajnimin e personelit mbi tematikat e menaxhimit të cilësisë, si dhe të përcaktojë përgjegjësitë mbi ekzekutimin e përgatitjes.

\subsubsection{Përgjegjësi}

- Individualizon kërkesat e përgatitjes;

- Veçon specialistët që do të marrin pjesë në përgatitje dhe trajnimet;

-Paraqet dhe planifikon pjesmarrjet në trajnime;

-Plotëson dhe rishikon dokumentat e lidhura me trajnimet;

- Arkivon dokumentat.

\subsubsection{Menaxhimi i kompetencës, ndërgjegjësimit dhe përgaditjes}

Për të gjithë personelin e punësuar të kompanisë, është përcaktuar një seri të dhënash që i përmbahen trajnimeve dhe eksperiencave të fituara nga ky punonjës përpara marrjes në punë, kërkesave formuese mbi tematikat e cilësisë si dhe aktiviteteve të zhvilluara në fushën e përgatitjes dhe trajnimet që lidhen me sistemin e menaxhimit të cilësisë të ndërmarrjes. 


\subsubsection{Planifikimi}

Nevoja për të zhvilluar trajnime (të brendshme/të jashtme) për përgatitjen e personelit zbatohet sipas udhëzimeve të planifikimit të aktiviteteve formuese. Dokumenti i paraqitur nga përgjegjësi i cilësisë.

\subsubsection{Menaxhimi i dokumentave dhe regjistrimeve}

Të gjitha skedat e personelit mbushen me informacionet që kanë të bëjnë me përgatitjen e fituar, detyrë e cila i atribuohet Përgjegjësit të Cilësisë i cili kordinon ndërhyrjet përgatitore e formuese dhe vendosë firmën e tij në procesverbalet ekzekutuese.

\subsubsection{Infrastruktura}

Menaxhmenti garanton përshtatshmërinë e infrastrukturave të nevojshme për zhvillimin korrekt të shërbimeve të ofruara, siç janë:

-zonat e punës,ku nënkuptohet hapësirat për mbledhjet dhe zyrat si dhe zonat prodhuese që janë kantieret

-disponueshmeri,rishikim dhe përshtatshmëri të mjeteve hardverike dhe softverike;

\subsubsection{Ambienti i punes}

Në dokumentat e brendshme të menaxhimit të sigurisë janë të specifikuara të gjithë faktorët e nevojshëm për të arritur një ambient pune sa ma të përshtatshëm me nevojat e punonjësve (nivelet e ndriçimit, temperaturat, lejet dhe veprimet e ndaluara, etj).

Të gjitha aktivitetet e ndërmarrjes janë të planifikuara dhe të drejtuara me qëllim që të garantojnë një ambient pune i cili nga këndveshtrimi njerëzor të garantojë kënaqësi, motivim, përfshirje dhe mirënjohje për arritjet.Përcjellëse e këtyre vlerave dhe përgjegjës për këtë është top menaxhmenti i kompanisë. 


\subsection{Planifikimi i realizimit të prodhimit}

Veprimet që janë të lidhura direkt me realizimin e prodhimeve që ofrohen nga kompania, gjithmonë kalojnë nëpër etapat e mëposhtme:

- PLAN - planifikohen veprimet;

- DO - zbatohet përherë ajo që është planifikuar;

- CHECK - kontrollohet që ajo që është zbatuar t’i korrespondojë asaj që është planifikuar;

- ACT - merren përsipër korrigjimet e shmangieve.

Në kuadër të planifikimit, në bashkëpunim me PC përcaktohen për çdo porosi, pikëpamjet e mëposhtme:

-kohën e duhur për realizimin me mirëpërcaktim të etapave të proceseve të veqanta si dhe të atyre që lidhen me to (programet e punës)

-burimet e disponueshme

-përgjegjësitë që lidhen me porosinë

-pajisjet dhe mjetet e punës

-objekti i porosisë (puna që do kryhet, veçoritë e saj teknike)

-plani i kontrollit që përmban veçoritë teknike dhe kriteret e pranushmërisë për përbërësit -punët gjysëm të zhvilluara dhe punimet që duhet të vihen nën kontroll

-koha e kontrolleve;

-burimet njerëzore të vetë personelit dhe të atij të jashtëm të ndërmarrjes

-mjetet e matjes, provës dhe kontrollit

\subsubsection{Proceset që lidhen me klientin -Përcaktimi i këkesave që lidhen me prodhimin}

Në lidhje me objektivat e cilësisë, menaxhmenti përcakton cilat do të jenë fushat e veprimit dhe proceset që lidhen me to, që ka ndërmend t’i ndërmarrë.

Në veçanti për çdo lloj tipi të procesit përcaktohen:

-kërkesat që lidhen me të gjithë procesin deri në dorëzimin e punës tek klienti;

-kërkesat që dalin nga ligjet apo urdhëresat;

-kërkesat specifike që ka vendosur menaxhmenti 
Kontrolli i kërkesave që lidhen me prodhimin, ka për qëllim garantimin e përputhshmërisë së furnizimit me kërkesat e vendosura, të deklaruara dhe/ose të nënkuptuara që janë kërkuar nga klienti dhe të paraqitura në dokumentat kontraktues si dhe mundësinë e arritjes të përmbushjes së kërkesave të klientit.

Në mënyrë specifike, nënkuptohet që:

-të shikohet mirë oferta duke e ballafaquar me kërkesën e klientit;

-të analizohet mundësia reale e ndërmarrjes për të realizuar kërkesat e kërkuara;

-të vendosen sektorët e firmës në lidhje me përmbushjen e kërkesave kontraktuese.

Periudha e aplikimit shtrihet gjatë fazës së pranimit të kërkesës së ofertës deri tek pranimi i porosisë së klientit.

Dokumentat kontraktues kanë këtë rend:

-kërkesa e ofertave e paracaktuar nga klienti;

-oferta pas ardhëse tekniko tregtare;

-porosia e ardhur nga klienti ose pranimi i ofertës tekniko tregtare;

-vërtetim porosie;

-shpërndarje e një urdhëri të mundshëm të brëndshëm ose të kërkesës për ndërhyrje.

\subsubsection{Komunikimi me klient}

Është top menaxhmenti ai që mban lidhjet me klientin ose përmes një të deleguari teknik të tijin. Gjatë fazës së përfundimit të kontratës, është DP që ndjek bashkëbisedimet me klientin me qëllim që të kthejë sa më të qarta dhe të kuptueshme të gjitha ato aspekte që mund të shkaktojnë keqkuptime ose gabime gjatë realizimit.

\subsubsection{Projektimi dhe zhvillimi-Planifikimi i projektimit dhe zhvillimit}

Kompania planifikon dhe mban nën kontroll të gjitha veprimtaritë e projektimit në mënyrë të tillë që të menaxhoj ndërlidhjen mes grupeve të ndryshme që janë të përfshirë në projektim, duke garantuar komunikime të vlefshme dhe shpërndarje sa më të qartë të detyrave dhe përgjegjësive. 
Ndërkohë veprimtaritë e projektimit dhe zhvillimit planifikohen në mënyrë të tillë që të përcaktojnë:

-Fazat e projektimit dhe të zhvillimit

-Veprimtaritë e rikontrollit,të verifikimit dhe të vlefshmërisë të përshtatura për çdo fazë të projektimit dhe zhvillimit

-përgjegjësitë dhe organet e autorizuara për projektimin dhe zhvilllimin

Fazat e projektimit realizohen përmes:

-përcaktimit të elementeve fillestare tek projektimi, duke vendosur më pas përcaktimin e elementeve përfundimtare që dalin nga projektimi;

Gjatë fazave të përshtatshme realizohen:

-rikontrolle për vlerësimin e rezultateve dhe /ose për të individualizuar problemet me zgjedhjet e mëposhtme;

-verifikime dhe vlefshmëri të projektimit dhe zhvillimit.

Ndryshimet e mundshme paraqiten në dokumenta të regjistruar dhe të përcaktuar.

\subsubsection{Elementet fillestare në projektim dhe zhvillim / Kontrollii ndryshimeve}

Për çfarëdo lloj prodhimi për t'u realizuar, gjatë fazës së projektimit përcaktohen elementet fillestare që nënkuptojnë atë që vijon më poshtë:

-Kërkesat e domosdoshme funksionale dhe rendimenti,

-Kërkesat a aplikueshme të bashkangjitura me to,

-Informacionet që rrjedhin nga projektime të mëparshme të ngjashme, si dhe të aplikueshme,

-Kërkesa te tjëra, në rast kur janë thelbësore për projektimin dhe zhvillimin.

Elementet e sipërpërmendur të përcaktuar si "elemente fillestare", janë rikontrolluar për të verifikuar:

-Përshtatshmërinë,

-Përplotshmërinë,

-Dyshime të mundshme. 
Në mënyrë që t'i përgjigjen “elementeve fillestare”, është redaktuar një dokument i posaçëm në të cilin evidentohen:

-Prodhimi që duhet të realizohet

-Specifikat teknike që duhet të ketë prodhimi

-Përgjegjësitë që lidhen me këtë fazë të projektimit

\subsubsection{Elementet përfundimtare që dalin nga projektimi dhe zhvillimi / kontrolli i ndryshimeve}

Qëllimi i kësaj pjese është që të përshkruajë modalitetet që përdoren për përcaktimin e elementeve përfundimtare që dalin nga projektimi dhe zhvillimi në mënyrë të tillë që të lejohet verifikimi i tyre gjatë përballjes me elementet fillestare përmes:

-Përmbushjes së kërkesave fillestare

-Informacioneve të përshtatshme për furnizimin, prodhimin dhe shpërndarjen e shërbimeve

\subsubsection{Rikontrolli, verifikimi, vlefshmëria e projektimit dhe zhvillimit}

Kompania gjatë fazave të përshtatshme të projektimit, zbaton rikontrolle sistematike të projektimit për:

-Vlerësimin e mundësisë për të vepruar në përputhje me kërkesat e përcaktuara;

-Përcaktimin e të gjithë problemeve dhe për të propozuar veprimet e nevojshme.

\subsubsection{Furnizimi -Procesi i furnizimit}

Procesi i furnizimit realizohet përmes kualifikimit të furnitorëve për materialet dhe shërbimet, duke u bazuar në mundësinë e tyre për të furnizuar me produkte dhe shërbime që përputhen me kërkesat e kompanisë.

Furnitorët ndahen nëdy kategori:

- Furnitorë prodhimesh

- Furnitorë sherbimesh

\subsubsection{Informacione për furnizimin}


Karakteristikat dhe kërkesat e prodhimeve që do të blihen, ju bëhen të ditura furnitorit në terma të qartë, të kuptueshëm dhe të pa ngatërrueshëm. Në këtë kuptim, është detyrë e padiskutueshme e kërkuesit, që të formulojë kërkesat e blerjes duke parashikuar një përshkrim sa më të gjerë të mundur të çdo karakteristike të prodhimit / materialit / shërbimit, duke evidentuar:

-Dëshmitë e prejardhjes

-Kërkesa teknike specifike

-Afatet e dorëzimit etj.

\subsubsection{Verifikimi i produkteve të furnizimit}

Ndërmarrja mund të kërkojë që të verifikohet përputhshmëria e furnizimeve me kërkesat e specifikuara, si tek furnitori ose gjatë furnizimit.

Ky verifikim nuk ia bën më të lehtë ndërmarrjes paraqitjen e produkteve të pranueshme ashtu si edhe nuk përjashton mundësine e një përjashtimi të mundshëm të mëpasëshëm të tyre, duke mos mundur të përdoret ky verifikim si provë për efikasitetin e kontrollit të cilësisë që është kryer tek furnitori

\subsubsection{Prodhimi dhe shperndarja e sherbimeve}

Kjo konsiston zhvillimin në kushte të kontrolluara të të gjitha aktiviteteve që influencojnë mbi cilësinë e prodhim/shërbimit të ofruar, me qëllim për arritjen e:

-verifikimit që burimet,njërzore dhe materiale,të përfshira në zhvillimin e aktiviteteve të janë të përshtatshme me detyrat që ju janë caktuar atyre;

-personeli ka për detyrë të kontrollojë gjendjen e mirëmbajtjes dhe funksionimin prefekt te automjeteve dhe paisjeve të përdorura;

-planifikimit dhe kontrollit të veprimeve për të verifikuar gjendjen e vazhdushmërisë së aktiviteteve të ndryshme dhe për të individualizuar faza të mundshme kritike ose të çorientimit gjatë zhvillimit të programit të punëve dhe të ndërrmar veprime të mundshme parandaluse ose korigjuse;

-verifikimit dhe kontrollit të korrektësisë së objektivave të përcaktuara me klientin ,me qëllim që të përfshihen ndryshimet e mundshme në planifikimin e aktivitetit;

-verifikimit që shërbimet e realizura të përmbushin plotësisht kërkesat e klientit ne kufijtë e funksionalitetit, besushmërisë, afateve të realizimit etj... 
-monitorimit dhe kontrollit të parametrave të përcaktura gjatë planifikimit;

-mirëmbajtjes në efiçencë prefekte të mjeteve që përdoren për mirëmbajtjen e programuar.

\subsubsection{Vlefshmëria e proceseve të prodhimit dhe shpërndarja e shërbimeve}

Për proceset prodhuese ku rezultati final nuk mund të verifikohet nga veprimet e mëpasëshme të monitorimit dhe matjeve dhe si rrjedhim difekte të mundshme mund të shfaqen vetëm pasi të vihet në përdorim dhe gjithashtu për të demostruar përputhshmërinë, e cila mbështetet në fakte objektive, që kërkesat të cilat lidhen me një përdorim ose aplikim të veçantë të jenë përmbushur, duhet të parashikohen si më poshtë:

-Metoda pune dhe kontrolle të përcaktura e të dokumentura pëmes udhëzimeve të posaqme teknike;

-Kritere për rikontrollin dhe miratimin e proçeseve nga ana e sektorëve përgjegjës,

-Miratim i pajisjeve që do të përdoren për proçeset,

-Kualifikim i personelit të ngarkuar me kryerjen e proceseve,

-Përcaktim i metodave për regjistrimin e aktiviteteve të punës dhe kontrollit të proçeseve, -Formalitete për "rivlersimin" e proçesit.

Këto të dhëna duhet të jenë qartësisht të kuptueshme nga formularët ose dokumentacioni i paraqitur.

\subsubsection{Identifikimi dhe ndarja}

Kompania ka përcaktuar kriteret dhe formalitetet për identifikimin dhe ndarjen e produkteve nga dokumentacioni që lidhet me të.

Këto kritere dhe formalitete duhet t'u aplikohen të gjitha produkteve gjatë krejt ciklit të tyre në kompani, duke filluar nga pranimi e deri tek dorëzimi i tyre.

Kjo veprimtari ka për qëllim që:

-të fiksohet një korrespondim i njëjtë mes materialeve dhe prodhimeve të realizuara;

-të garantohet që vetëm materialet e përshtatshëme gjatë punimit dhe vetëm produktet $\mathrm{e}$ përfundura dhe të autorizura të jepen për t'u dorëzuar;

-të lejohet një verifikim i shpejtë i prodhimit dhe gjendjes së tij të punës ne procesin e nderrmarjes 


\subsubsection{Materialet e mbrojtura të klientëve}

Qëllimi i kësaj pjese është përcaktimi i formaliteteve për menaxhimin e materialeve të sjella nga furnitori, siç janë produktet, materialet, listat emërore, përshkrimet, veçori të rezervuara dhe githçka që nevojitet për të realizuar punën dhe ambientet e punës.

Kjo i aplikohet "materialeve ose pronat intelektuale" të sjella nga klienti për realizimin e sherbimit, dhe si rrjedhojë janë përshkruar kriteret duke pretenduar që këto veprime të jenë në përputhje me legjislacionin që ju perket.

\subsubsection{Kriteret e menaxhimit dhe registrimet e cilësisë}

Formalitetet operuese të menaxhimit dhe regjistrimit të cilësisë të përcaktuara tek Manuali i Cilësisë (të shihet pj. 7.5.5) që ju aplikohen materialeve të blera direkt nga kompania, ju aplikohen edhe materialeve të furnizuara nga furnitori, në mënyrë që vetë ato të jenë të kontrollur, magazinuar, ruajtura dhe mirëmbajtur si produkte të blera nga vetë kompania dhe do t'i njoftohen klientit për çdo humbje, dëmtim ose jopërshtatshmëri gjatë përdorimit nën kujdesin e DPRODH.

\subsubsection{Lista e materialeve të sjella nga furnitori}

Aty ku për çfarëdo lloj arsyeje, mund të parashikohet që furnitori të sjellë materiale dhe gjithçka tjetër që është e nevojshme për realizimin e punës, përcaktohet një listë e posaçme e këtyre materialeve të përdorura në mënyrë të kontrolluar.

\subsubsection{Rujtja e produkteve}

Kompania parandalon dëmtimin dhe humbjen e identifikimit me qëllim gjetjen e materialit, nga momenti i pranimit deri tek dorëzimi i punës së kryer, përmes kontrolleve të veprimtarive të lëvizjes, magazinimit, ruajtjes dhe dorëzimit të materialit, të pajisjeve dhe të veprimeve të kryera. Të dhenat e punes ruhen në menyre elektronike gjatë punes/kryerjes së sherbimit dhe në fund te sherbimit hidhen në CD për cdo kompani. Behen disa kopje. Një pjesë e materialeve ruhen në leterë dhe në arkiv.

\subsubsection{Mbajtja nën kontroll e monitorimit dhe matjes}

Menaxhimi operativ i pajisjeve të matjes dhe monitorimit, aktualizohet në mënyrë të tillë që të mund të jetë i disponueshëm një sistem kontrolli i mjeteve të përdorura, me qëllim që të garantohet besueshmëri për proceset prodhuese dhe për matjet e kryera. 
Pajisjet zgjidhen në bazë të funksionit që kanë ndikim tek procesi i punimit, në mënyrë që të garantohet që shkalla e pasigurisë të jetë e ditur dhe e përputhur me shkallën e saktësisë që është e nevojshme për kërkesat e ndërmarrjes.

Për gjithë secilen pajisje është paraqitur një skedë listore tek e cila paraqiten informacionet e mëposhtme:

-Numri i identifikimit

-Përshkrim i mjetit

-Ndërtuesi

-Amza e ndërtuesit që identifikon mjetin (aty ku përdoret)

-Enti (i brendshem ose i jashtëm) i ngarkuar për kryerjen e kaliblimit (aty ku përdoret)

-Referimenti i kalibrimit specifik që është parashikuar për kryrjes e kalibrimit (aty ku aplikohet)

-Rangu operativ dhe shkalla e precizionit

-Periudha e vlefshmërisë së kalibrimit

\subsection{Matja, analiza dhe pritshmeritë}

Kompania planifikon dhe aktualizon proceset e monitorimit, matjes, analizimit dhe përmirësimit me qëllim që:

-të tregojë përputhjen e shërbimit të kryer, 
-të garantojë përputhjen e sistemit të cilësisë së kompanisë,

-të përmirësojë në mënyrë të vazhdueshme efikasitetin e sistemit të garantimit të cilësisë se saj.

Procesi i monitorimit dhe i matjes kontrollohet nga kontrollet vjetore dhe të pjesshme, shmangiet e përcaktuara në kontratë kontrollohen përmes trajtimit të jopërputhshmërive, përmirësimi i vazhdueshem kontrollohet përmes veprimeve parandaluese dhe korrigjuese.

\subsubsection{Monitorimi dhe matja / knaqësia e klientit}

Për të kuptuar perceptimin që klientat kanë për shërbimet që u ofrohen atyre, periodikisht ose menjëherë pas dorëzimit dhe përfundimit të porosisë, bëhen studime, të cilat programohen në formë rikontrolli për vazhdimin e duhur të sistemit të administrimit të cilësisë tek sherbimi, dhe këto mund të jenë:

-të llojit direkt pëmes pytësorve, bashkëbisedimeve direkte, sinjalizimeve nga ana e të gjithë sektorëve të kompanisë në lidhje me porositë e posaqme;

-të llojit indirekt përmes një vlersimi të besnikërisë së klientve, ose përmes një përmbledhje të dhënash mbi paraqitjen e shërbimeve të ofruara.

\subsubsection{Kontrollet e brendshme}

Kontrolli i brendshëm konsiston në një testim sistematik dhe të pavarur, i drejtuar për të vlersuar nëse aktivitetet e tilla janë zhvilluar në përputhje me rregullat e përgjithshme dhe me procedurat e specifikuara, si për mënyrat ashtu edhe për kohëzgjatjen; verifikimi gjithashtu do të saktësojë nëse rregullat dhe procedurat referuese do të jenë të përshtatshme për realizimin e objektivave të cilësisë të përcaktuara në politikën e kompanisë për cilësinë.

Aktiviteti i kontrolleve është efikas nëse është i mirë planifikuar, dhe për këtë qëllim është e nevojshme që të paraqitet një program dhe menjëherë pas kësaj një plan kontrollesh koherente duke përcaktuar:

-objektivat

-duke evidentuar jo përputhshmëritë mes rezultateve të pritshme dhe të atyre të konstatuara -të përcaktoj dhe të nisë veprimet korigjuse ose parandaluse për përmisimin e vazhdueshëm 
Kontrollet e brendshme planifikohen dhe zbatohen të paktën njëherë në vit per gjithësecilin proces të sistemit. Rezultatet paraqesin gjithashtu në mënyrë objektive nevojën e mundshme për të zvogluar, eliminuar dhe mbi të gjitha parandaluar shfaqjen e jokonformiteteve.

Në fund të çdo kontrolli, auditët duhet të redaktojne një raport i cili do të përmbajë dokumentat që evidentojnë atë ç'ka u paraqit.

Ky raport do të përmbajë të dhënat e mëposhtme:

-Të dhënat e ekzekutimit të kontrolleve

-Përshkrim i sistemit të cilësisë së kompanis i cili është kontrolluar

-Pikat e forta

-Zonat e përmirësimit

-Rekomandime

-Personeli i intervistuar

\subsubsection{Monitorimi dhe matja e proceseve}

Menaxhmenti verifikon në formën e rikontrollit duke u bazuar:

-Tek raportet e përgjegjësit të cilësisë mbi shkallën e kënaqësisë së klientit,

-Tek raportet e përgjegjësit të cilësis mbi rezultatet e kontrolleve të brëndshme, pjesa II dhe III;

-tek lëvizjet e tregut;

-tek treguesit e matjes së proceseve pra tek pika 4.1 e manualit të cilësisë

-tek përshtatja e proceseve të zbatuara, rezultatet e të cilëve paraqiten tek statistikat teknike.

\subsubsection{Monitorimi dhe matja e prodhimeve}

Kontrolli në hyrje i materialeve bëhet me qëllim për të mënjanuar që prodhimet që vlerësohen si të jopërputhshme, të mos futen dhe përdoren në procesin prodhues të shërbimit.

Këto kontrolle që janë të llojit teknik, cilësor dhe administrativ, kanë të bëjnë me:

-përputhshmërinë me kriteret e pranimit të përcaktuar brenda ndërmarrjes ose kriteret $\mathrm{e}$ përcaktuara të porosisë,kontrollet direkte me verifikimin e llojit dhe të sasisë;

-verifikimin e përputhshmërisë mes dokumentave shoqëruese dhe kërkesës së blerjes ;

-verifikim e përputhshmërisë së materialit me specifikat teknike të përmendura te urdhëresa e blerjes; 
-verifikim e paprekshmërisë së ambalazhimit dhe me kthimin e menjëhershëm tek transportusi në rastet e një rezultati negativ.

\subsubsection{Mbajtja nën kontrolle prodhimeve jokonforme}

Jokonformitetet mund të dalin:

-gjatë procesit të pranimit

-gjatë procesit të prodhimit

-në feed-back nga ana klientit

Sektori i Menaxhimit të Cilësisë, pasi shfaqen jopërputhshmëritë, do të vihet në punë për të:

-analizuar arsyet e jopërputhshmërive dhe rrjedhimisht për të nisur procesin e veprimeve korrigjuese.

Në momentin e shfaqjes së një jokonformiteti, çdo punonjës i ndërmarrjes ka për detyrë të informojë përgjegjësin e sektorit të kompanisë ku punon .

\subsubsection{Analiza e të dhënave}

Përdorimi i teknikave statistikore mundëson garantimin e cilësisë së shërbimit.

Përgjegjësi i Cilësisë (Menaxhmenti i Ndërmarrjes) procedon me kontrollin e të dhënave që lidhen me:

-kënaqësinë e klientit;

-përputhshmëri me kerkesat e prodhimit;

-karakteristikat e proceseve dhe të prodhimeve duke përfshirë këtu edhe mundesinë e veprimeve korigjuse;

-paraqitjen ose gjendjen e furnitorëve

Regjistrimi i rezultateve përbën "Historinë e Cilësisë”, e cila kur të analizohet, do të mundësojë:

-garantimin e një niveli më të lartë cilësor;

-promovimin e vazhdueshëm të një përmirësimi të cilësisë në shërbimin e ofruar.

\subsubsection{Përmirësimi i vazhdueshëm}

Kompani çdo situatë që lidhet me cilësinë (e shfaqur ose e mundshme), duhet të përballohet me veprime të cilat duhet të përmirësojnë vazhdimisht SAC. Përgjegjësi i menaxhimit të cilësisë, meqënëse është përgjegjës dhe ekzekutues korrekt i veprimeve korrigjuese dhe parandaluese, duhet të jetë në gjendje që të vlerësojë të gjitha propozimet për përmirësim të cilat bëhen nga 
përgjegjës të ndryshëm, të kujdeset për mbledhjen e të githa informacioneve dhe të dhënave të disponueshme (rregjistrimet e cilësisë, ankesat e klientëve, analizat statistikore, veprimet e mëparshme korrigjuese) në mënyrë që të mund t'i administrojnë për të arritur një përmirësim të vazhdueshëm, në bashkëpunim me drejtorinë gjatë të gjitha fazave të punës duke përdorur:

-politikën dhe objektivat për cilësinë;

-rezultatet e kontrolleve;

-analizën e të dhënave;

-veprimet korrigjuese dhe parandaluese si dhe rikontrollet e bëra nga menaxhmenti

\subsubsection{Veprimet korigjuse}

Veprimet korrigjuese përcaktohen si mjete për të eliminuar shkaqet e jo përputhshmërive me qëllim që ato të mos përsëriten.

Për këtë lloj aktivititeti, është përcaktuar një proçedurë në të cilën precizohen elementet e mëposhtme:

-Rikontrolli i jopërputhshmërive

-Përcaktimi i shkaqeve të jo përputhshmërive

-Vlerësimi i nevojës pë të ndërmarrë veprime të cilat shmangin përseritjen e

jo përputhshmërive

-Përcaktimi dhe zbatimi i veprimeve të nevojshme

-Rregjistrimi i rezultateve të veprimeve të zbatuara

-Rikontrolli i veprimeve korrigjuese

Të gjitha këto veprimtari janë përmbledhur në diagramën e illustruar më poshtë

\subsubsection{Veprimet parandaluse}

Kompania, duke u nisur nga analiza e informacioneve të mbledhura nga të dhënat zyrtare të sistemit të cilësisë, siç janë: raportet e jokonfomriteteve, ankesat e klientëve, raportet e kontrolleve, rregjistrimet e cilësisë, analiza e statistikave mbi prodhimet dhe/ose mbi proçeset, dhe rikontrollet 
e drejtorisë, fillon veprimet e nevojshme për të eliminuar shkaqet e jo përputhshmërive të mundshme me qellim mos përsëritjen e tyre.

Këto veprime, të përcaktuara si korrigjuese, janë të përshtatura për shkaqet e jokonformiteteve të shfaqura.

\section{Metodologjia}

4.1 Procedura e auditimit të brendshëm / Qëllimi dhe objektivat 
Kjo procedurë ka për qëllim të përcaktojë përgjegjësitë, aktivitetet e realizuara dhe sigurimin që sistemii menaxhimit të cilësisë të aplikohet korrektësisht në të gjitha procedurat e tij si dhe të vleresojë efikasitetin e sistemit të menaxhimit të cilësisë.

\subsubsection{Fusha e aplikimit}

Një procedurë e tillë aplikohet në aspektet e më poshtme të sistemit të menaxhimit të cilësisë:

-Struktura organizative

-Procedurat

-Dokumentacioni teknik

-Regjistrimi i cilësisë

-Përgjegjësia e burimeve

\subsubsection{Referimet ligjore}

\begin{tabular}{|l|l|}
\hline & Sistemi i menaxhimit të cilësisë \\
\hline EN ISO 9000 : 2005 & Sistemi i menaxhimit të cilësisë: bazat dhe terminologjia \\
\hline EN ISO 9004 : 2009 & $\begin{array}{l}\text { Sistemi i menaxhimit të cilësisë: Udhëzues për përmiresimin e } \\
\text { vazhdueshem }\end{array}$ \\
\hline Manuali i cilesise & Edicioni i fundit \\
\hline PRD-03-MOD-03 & $\begin{array}{l}\text { Procedura: Manaxhimi i jokonformiteteve. Veprimet korrigjuese dhe } \\
\text { parandaluese }\end{array}$ \\
\hline PRD-02 & Procedura: Rishqyrtimi i drejtorisë \\
\hline
\end{tabular}

Tab 5.Referimet ligjore

\subsubsection{Përgjegjësit}

Drejtoria / Përgjegjësi për siguri të ushqimit / Përgjegjesi i procesit / Konsulenti i jashtëm 


\subsubsection{Mënyra e ekzekutimit}

\section{Planifikimi i auditimeve}

MC përcakton çdo vit një "Plan Auditimesh" që mbulon të gjitha aktivitetet e kompanisë dhe përmban të paktën dy auditime për çdo funksion. Ky plan përcakton për çdo auditim të brendshëm:

-Inspektorin përgjegjës të auditimit

-Inspektorin e mundshëm ndihmës

-Muajin e përafërt për verifikimin e auditimeve

-Përfshin në planifikim auditimet e mundshme, që mund të paraqiten të nevojshme gjatë vitit, përveç auditimeve të planifikuara.

Një auditim mund të ketë si objekt më shume se një aktivitet.

\section{Auditimet e jashtëzakonshme}

Përveç auditimeve të planifikuara në programin vjetor të auditimeve, gjatë vitit mund të verifikohen auditime të tjera të pa programuara, si pasoje e:

-Një analize të pergjithshme të një procedure që ka të bëjë me një aktivitet të caktuar.

-Një jokonformiteti të përsëritur ose i sistemit me interes të konsiderueshëm, mbi një aktivitet të caktuar.

-Një jokonformiteti me interes për ndërmarrjen të njoftuar nga klienti ose nga strukturat publike e ligjore të përcaktuara.

-Një ndryshimi domethënës në organizim që influencon një aktivitet të caktuar.

-Një ndryshimi thelbësor të ciklit të prodhimit ose shërbimit.

-Një auditim të mbylljes urgjente të një veprimi korrigjues të veçantë.

-E kërkon ose e këshillon një klient i mundshëm ose i konsoliduar.

\subsubsection{Objektivat e auditimeve}

Objektivat e një auditimi janë:

- Të verifikohet që dokumentacioni është konform me standarde; 
- Të verifikohet që aktivitetet e kryera janë në konformitet me Sistemin e dokumentuar të Cilësisë

-Të verifikohet gjendja e realizimit të objektivave të përmirësimit të përcaktuara nga "Analiza e Drejtuesve" (PRD-02-MOD-01)

\subsubsection{Realizimi i auditimit}

MC të paktën dy javë përpara datës së Auditimit të parashikuar për një proces specifik, paraqet në tabelën e njoftimeve komunikimin e datës së Auditimit dhe përcakton në mënyrë të qartë procesin që do të auditohet.

Në të njëjtën kohë përcakton një mbledhje në të cilën duhet të marrin pjesë të gjithë auditorët e zgjedhur për kryerjen e Auditimit si dhe përgjegjësit e funksioneve përkatëse që do te auditohen, në mënyrë që Auditimi të përgatitet në detajet minimale të nevojshme dhe për të përgatitur listat krahasuese në bashkëpunim me Përgjegjësit e Zonës, duke mbajtur parasysh nivelin e rëndësisë së aktivitetit që do të auditohet.

\section{Auditimi kryhet sipas fazave të mëposhtme:}

1. Mbledhja paraprake mbahet nga auditori përgjegjës në të cilën merr pjesë i gjithë personeli i procesit që do të auditohet.

Qëllimi i mbledhjes është prezantimi i grupit të vlerësuesve të ngarkuar për auditimin si dhe të ilustrohet aktiviteti dhe oraret e auditimit në metodat e realizimit të tij.

Analiza e aktivitetit të vlerësimit të konformitetit në metodat e përshkruara në procedurë duke u nisur nga verifikimi i mbylljës së mos-konformiteteve të dala nga auditimi i mëparshëm dhe të diskutuara në "Analizën e Drejtuesve"

Auditori realizon auditimin mbi rezultatet e planifikuara, proçedurat dhe instruksionet e veprimit të Sistemit të Cilësisë për funksionin dhe/ose zonën në shqyrtim, duke i krahasuar me evidencat e aktiviteteve të kryera.

\section{Përgatitja e "Raportit të Auditimit"}

Auditori përgatit "Raportin e Auditimit" që duhet të firmoset nga Menaxheri i Funksionit dhe /ose i zonës dhe nga vetë Audituesi.

"Raporti i Auditimit" përmban të dhënat e mëposhtme:

-Numrin progresiv

-Datën dhe objektin 
-Funksionin ose zonën që i nënshtrohet auditimit

-Auditorin përgjegjës

-Auditorin e mundshëm ndihmës

-Dokumentet referuese

-Jokonformitetet e zbuluara

-Konkluzionet dhe komentet shtesë

-Firmën e Auditorit Përgjegjës dhe të Menaxherit të Funksionit.

3.Mbledhja përfundimtare ku merr pjesë Përgjegjësi i Funksionit të audituar në të cilën komunikohen rezultatet e auditimit dhe nëse janë zbuluar jokonformitetet, përcaktohen dhe dakordohet mbi veprimet përkatëse korrigjuese të cilat regjistrohen në "Raportin e Auditimit" dhe kalohen edhe në "Raportin e jokonformiteteve"

Auditori i dorëzon pastaj "Raportin e Auditimit" Menaxherit të Cilësisë i cili kujdeset për arkivimin e tij dhe i jep një kopje Menaxherit të Funksionit dhe/ose të Zonës.

MC i regjistron gjithashtu jokonformitetet e zbuluara edhe në "Raportet e jokonformiteteve" që menaxhohen siç është treguar në proçeduren përkatëse.

\title{
4.1.7 Kualifikimi i auditorëve
}

Auditorët e brendshëm duhet të kenë kryer kualifikime sipas njërës nga metodat e mëposhtme:

- Kurs trajnimi rreth standarteve ISO 9001 dhe mbi auditimet dhe standartet 19011-Trajnim i njëvlershëm nëpërmjet bashkëpunimit me personel të jashtëm në të paktën tre auditime

\subsection{Plani i auditimit}

\author{
Plani i auditimit
}




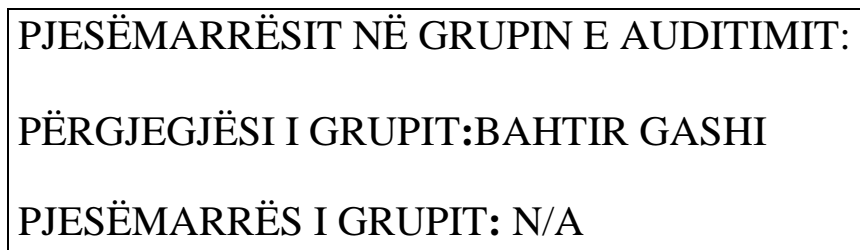

Objekti i auditimit:

Konformiteti i Sistemit të Menaxhimit të Cilësisë me kërkesat EN ISO 22000:2005

\begin{tabular}{|l|l|l|l|l|}
\hline $\begin{array}{l}\text { Funksionet e audituara } \\
\text { kompanisë }\end{array}$ & Argumentat & Auditor & Data & Ora \\
\hline Pergjegjesi i funksionit & Mbledhja hapëse & Bahtir \\
Gashi & 25.11 .2019 & 09.00 \\
\hline $\begin{array}{l}\text { Drejtoria } \\
\text { Cilësia }\end{array}$ & $\begin{array}{l}\text { Qasja sipas procesit, përgjegjësit e } \\
\text { drejtorisë, vëmendja e fokusuar ndaj } \\
\text { klientit, politika e cilësisë, } \\
\text { planifikimi, përgjegjësitë, autoritet } \\
\text { dhe komunikimi, dokumenat e SC, } \\
\text { dokumenta me të dhëna dhe rekorde. }\end{array}$ & Bahtir Gashi & 25.11 .2019 & Bahtir \\
\hline $\begin{array}{l}\text { Drejtoria } \\
\text { Cilësia }\end{array}$ & $\begin{array}{l}\text { Azhornimi i normave dhe ligjeve, } \\
\text { analiza e të dhenave, mbrojtja dhe } \\
\text { menaxhimi i të dhënave elektronike, } \\
\text { dokumenta me të dhëna dhe rekorde. }\end{array}$ & Gashi & 25.11 .2019 & 09.15 \\
\hline $\begin{array}{l}\text { Drejtoria } \\
\text { Cilësia }\end{array}$ & $\begin{array}{l}\text { Inspektimet e brendshme, përmisimi, } \\
\text { veprimet korrigjuese, veprimet } \\
\text { parandaluese, kënaqësia e klientit, } \\
\text { rishikimi i drejtorisë, dokumenta me } \\
\text { të dhëna dhe rekorde. }\end{array}$ & $\begin{array}{l}\text { Bahtir Gashi } \\
\text { Input i projektimit, programimi i } \\
\text { projektit, përpunimi i projekteve, } \\
\text { verifikime, rishqyrtime, validime, } \\
\text { output i projektimit, modifikimet e } \\
\text { projektimit, dokumenta me të dhëna }\end{array}$ & Bahtir \\
Drejtoria \\
Cilësia
\end{tabular}




\begin{tabular}{|c|c|c|c|c|}
\hline & $\begin{array}{l}\text { dhe rekorde. (Verifikimi i } \\
\text { përjashtimit) }\end{array}$ & & & \\
\hline & Pushim & Bahtir Gashi & 25.11 .2019 & 12.30 \\
\hline $\begin{array}{l}\text { Shitjet dhe } \\
\text { Cilësia }\end{array}$ & $\begin{array}{l}\text { Procese te lidhura me klientin, } \\
\text { përpunim dhe rishqyrtimi i ofertave, } \\
\text { rishqyrtimi i konfirmimit të } \\
\text { urdhërave të klientit, modifikimet e } \\
\text { dokumentave kontraktuese, } \\
\text { menaxhimi i listës së çmimeve, } \\
\text { lëshimi i urdhërave të prodhimit; } \\
\text { menaxhimi i dërgimit të produktit } \\
\text { përfundimtar, komunikimi me } \\
\text { klientet, menaxhimi i reklamimeve, } \\
\text { dokumenta me të dhëna dhe rekorde. }\end{array}$ & $\begin{array}{l}\text { Bahtir } \\
\text { Gashi }\end{array}$ & 25.11.2019 & \\
\hline $\begin{array}{l}\text { Drejtoria } \\
\text { Cilësia }\end{array}$ & Menaxhimi i personelit & Bahtir Gashi & 25.11 .2019 & 15.00 \\
\hline DA & $\begin{array}{l}\text { Kualifikimi i furnitorve, dokumenta } \\
\text { dhe rekorde. }\end{array}$ & $\begin{array}{l}\text { Bahtir } \\
\text { Gashi }\end{array}$ & 25.11 .2019 & \\
\hline $\begin{array}{l}\text { Blerjet } \\
\text { Magazina }\end{array}$ & $\begin{array}{l}\text { Blerjet, ruajtja e produkteve, } \\
\text { gjurmueshmeria, pronësia e klientit, } \\
\text { trajtimi i jokonformiteteve, } \\
\text { dokumenta me të dhëna dhe rekorde. }\end{array}$ & Bahtir Gashi & 25.11 .2019 & \\
\hline
\end{tabular}




\begin{tabular}{|l|l|l|l|l|}
\hline Prodhimi & $\begin{array}{l}\text { Mbajtja nën kontroll e procesit } \\
\text { prodhues, prova dhe kontrolle në } \\
\text { prodhim, kontrolli final, trajtimi i } \\
\text { jokonformiteteve, dergesa, validimi i } \\
\text { proceseve të prodhimit, të realizimit, } \\
\text { të shërbimit, dokumenta me të dhëna } \\
\text { dhe rekorde. }\end{array}$ & Gahtir & 25.11 .2019 & \\
\hline Mirëmbajtja & $\begin{array}{l}\text { Infrastruktura,menaxhimi i } \\
\text { mirëmbajtjes,menaxhimi i } \\
\text { hardverëve dhe softverëve,ambientet } \\
\text { e punës, dokumenta me të dhena dhe } \\
\text { rekorde. }\end{array}$ & Bahtir Gashi & 25.11 .2019 & \multirow{2}{*}{15.00} \\
\hline Cilësia & $\begin{array}{l}\text { Mbajtja nën kontroll e monitorimit të } \\
\text { pajisjeve të matjes, menaxhimi i } \\
\text { aparaturave, monitorimi dhe matja e } \\
\text { proceseve dhe produkteve }\end{array}$ & Gashi & 25.11 .2019 & 17.45 \\
\hline Përgjegjësit & $\begin{array}{l}\text { Mbledhja përmbledhëse: Mbyllja e } \\
\text { verifikimit ora 19.00 }\end{array}$ & Bahtir & Gashi & 25.11 .2019 \\
\hline
\end{tabular}




\subsection{Raporti i të gjeturave}

\begin{tabular}{|l|l|l|l|}
\hline \multicolumn{2}{|l|}{ Raporti i të gjeturave } \\
\hline Raporti nr: 01 & Data : & Standardi referues: & Zona e audituar: \\
& 25.11 .2019 & ISO 22000:2005 & Të gjitha \\
\hline
\end{tabular}

\begin{tabular}{|l|l|l|l|l|}
\hline \multicolumn{3}{|l|}{ Përbërja e grupit të auditimit } \\
\hline Auditori përgjegjës : & Bahtir Gashi & \multicolumn{3}{l|}{} \\
\hline Auditori ndihmës : & N/A & K & JK \\
\hline Auditori ndihmës : & N/A & X & \\
\hline Pika & Kërkesat e Standardit & X & \\
\hline A & Manuali është në formë të kontrolluar ? & X & \\
\hline B & Është prezent gjendja e rishikimit të Manualit/Seksioneve? & X & \\
\hline C & A ka një tregues të përmbajtjes ? & X & \\
\hline D & A ka një korelacion me paragrafet e Standardit EN ISO 22000: 2005 ? & & \\
\hline E & A janë prezente procedurat e rishikura? &
\end{tabular}

P4. Sisitemi i menaxhimit të sigurisë ushqimore

\begin{tabular}{|c|c|c|c|c|c|}
\hline Paragrafi & & Zona/Argumenti & NA & $\mathbf{K}$ & JK \\
\hline 4.1 & Kërkesa të përgjithshme & Drejtimi & & $\mathrm{X}$ & \\
\hline \multicolumn{6}{|c|}{$\begin{array}{l}\text { Kompania ka stabilizuar, dokumentuar dhe mbajtur në përmirësim të vazhdueshëm dhe efikas Sistemin e } \\
\text { Menaxhimit të Sigurisë Ushqimore konform Standardit ISO 22000:2005. Kompania ka identifikuar } \\
\text { proceset referuese për Menaxhimin e Sigurisë Ushqimore, ndërveprimet si dhe ka përcaktuar kriteret dhe } \\
\text { metodat për të siguruar funksionimin dhe kontrollin efikas (matje dhe analiza). }\end{array}$} \\
\hline Paragrafi & & Zona/Argumenti & NA & $\mathbf{K}$ & JK \\
\hline 4.2 & $\begin{array}{lcll}\begin{array}{l}\text { Kërkesat } \\
\text { dokumentacionin }\end{array} & \text { lidhura } & \text { me }\end{array}$ & Cilësia & & $\mathrm{X}$ & \\
\hline 4.2 .1 & Të përgjitshme & & & & \\
\hline
\end{tabular}


Procedurat përkatëse dokumentojnë në mënyre korrekte Sistemin e Menaxhimit të Sigurisë Ushqimore në të gjitha pjesët e nevojshme të saj. Ato përmbajnë deklarimin mbi politikat për sigurinë ushqimore, proçedurat dhe regjistrimet, si edhe dokumenta për të siguruar efikasitet.

\subsection{2 $\quad$ Mbajtja nën kontroll e dokumenteve}

Procedura përkatëse (PRD-08 Rishikimi 3)përshkruan në mënyrë të detajuar menaxhimin dhe mbajtjen nën kontroll të dokumentacionit.

\section{\begin{tabular}{l|l}
4.2 .3 & Mbajtja nën kontroll e regjistrimeve
\end{tabular}}

Në përputhje me procedurat, kompania plotëson dhe kontrollon të gjitha rregjistrimet.

\begin{tabular}{|l|l|l|l|l|l|}
\hline ParagrafI & & Zona/Argumenti & NA & K & JK \\
\hline 5.1 & Përkushtimi i Drejtimit të lartë & Cilësia & & X & \\
\hline
\end{tabular}

Menaxhmenti i Lartë përkushtohet në zhvillimin dhe implementimin e Sistemit të Menaxhimit të Sigurisë Ushqimore, si dhe kërkon përmirësimin e vazhdueshëm të efikasitetit të tij duke komunikuar në brendësi të kompanisë rëndësinë e përmbushjes së kërkesave të Sistemit.

\begin{tabular}{|l|l|l|l|l|l|}
\hline Paragrafi & & Zona/Argumenti & NA & K & JK \\
\hline 5.2 & Politika e Sigurisë Ushqimore & Drejtimi & & $X$ & \\
\hline
\end{tabular}

Politika e Sigurisë Ushqimore është përshtatur në përputhje me qëllimet dhe objektivat e kompanisë, kujdesin dhe sigurinë ushqimore ndaj secilës palë të interesuar dhe rritjen e përmirësimit të vazhdueshëm të performancës. Duke e përdorur si referim për përcaktimin dhe sigurimin e objektivave, ajo u është komunikuar stafit të brendshëm dhe personave të tjerë të jashtëm të interesuar. Politika e Sigurisë Ushqimore është e afishuar në ambjentet e kompanisë. Ajo është e datës 25.04.2019

\begin{tabular}{|l|l|l|l|l|l|}
\hline Paragrafi & \multicolumn{1}{|l|}{ Zona/Argumenti } & NA & K & JK \\
\hline 5.3 & $\begin{array}{l}\text { Planifikimi i Sistemit të Menaxhimit } \\
\text { të Sigurisë Ushqimore }\end{array}$ & Drejtimi & X & \\
\hline
\end{tabular}

Kompania ka planifikuar dhe mirëmbajtur sistemin e menaxhimit të sigurisë ushqimore. Ajo parashikon aktivitetet dhe burimet e nevojshme për të kënaqur politikën e kompanisë.

Përcakton objektivat që duhen monitoruar dhe indikatorët e sigurisë ushqimore në formularin PRD-05MOD-01, Rishikimi 3.. Ky planifikim është koherent dhe i integruar me planifikimet e tjera të kompanisë.

\begin{tabular}{|l|l|l|l|l|l|}
\hline Paragrafi & & Zona/Argumenti & NA & K & JK \\
\hline 5.4 & Përgjegjësitë dhe autoriteti & Drejtimi & & $X$ & \\
\hline
\end{tabular}

Përgjegjësitë dhe autoriteti janë të përcaktuara qartë në organigramën e kompanisë PRD-06-ORG datë 03.04.2019. Personat përkatës janë të njohur me funksionet dhe detyrat e tyre, ku është parë se në 
organigram Paloka Berisha mban pozicionin e Administratorit. Ai ka miratuar strukturën e organigramës dhe secili punonjës ka përgjegjësi të specifikuar.

\begin{tabular}{|l|l|l|l|l|l|}
\hline Paragrafi & & Zona/Argumenti & NA & K & JK \\
\hline 5.5 & $\begin{array}{l}\text { Përfaqësuesi i Grupit të Sigurisë } \\
\text { Ushqimore }\end{array}$ & Drejtimi & & X \\
\hline
\end{tabular}

Përfaqësuesi i menaxhmentit të lartë për Sigurinë Ushqimore është Manaxheri i Sigurisë Ushqimore. Ekziston autorizimi përkatës nga administratori i datës 03.04.2019.

\begin{tabular}{|l|l|l|l|l|l|}
\hline Paragrafi & & Zona/Argumenti & NA & K & JK \\
\hline 5.6 & Komunikimet & Drejtimi & & $X$ & \\
\hline
\end{tabular}

Përmes komunikimeve jepen njofimet dhe lajmërimet nga menaxhmenti i Lartë, të cilat afishohen në këndin e posaçëm të lajmërimeve në ambientet e brendshme te kompanisë.

\section{\begin{tabular}{l|l}
5.6 .1 & Komunikimi i jashtëm
\end{tabular}}

Çdo person i jashtëm, si p.sh. furnitor, klient, autoritet, etj vihet në dijeni për njoftimet e kompanisë përmes kontakteve të krijuara dhe të ofruara nga kompania për sa i përket Sigurisë Ushqimore. Është shpallur Politika e Sigurisë Ushqimore më datë 25.04.2019 e cila shpreh angazhimin e kompanisë për të siguruar kujdesin ushqimor.

\section{\begin{tabular}{l|l}
5.6 .2 & Komunikimi i brendshëm
\end{tabular}}

Çdo punonjës vihet në dijeni për komunikimet e brendshme me anë të urdhërave të brendshëm dhe afishimeve në këndin e lajmërimeve. Këto janë informacione për vendet e punës, mbledhjet e administratës etj. Është bërë komunikimi se do të kryhet Audit i Brendshem i kompanisë për ISO 22000:2005 më datë 25.11.2019, ku të gjithë punonjësit duhet të jenë prezent.

\begin{tabular}{|l|l|l|l|l|l|}
\hline Paragrafi & \multicolumn{1}{|c|}{ Zona/Argumenti } & NA & K & JK \\
\hline 5.7 & $\begin{array}{l}\text { Gatishmëria dhe veprimet në } \\
\text { kushtet e emergjencës }\end{array}$ & Drejtimi & & \\
\hline
\end{tabular}
Kompania ka stabilizuar një procedurë lidhur me përgatitjen dhe veprimet e ndërmarra në kushtet e emergjencës. Gatishmëria dhe veprimet në kushtet e emergjencës pranë kompanisë kryhen në bazë të proçedurës PRD-02, Rishikimi 3, Date 03.04.2019. Ekziston regjistri dhe raportet e emergjencës.

\begin{tabular}{|l|l|l|l|l|l|}
\hline Paragrafi & & Zona/Argumenti & NA & K & JK \\
\hline 5.8 & Shqyrtimi i Drejtimit të Lartë & Drejtimi & & $X$ & \\
\hline Shqyi
\end{tabular}

Shqyrtimi i menaxhmentit të lartë pranë kompanisë kryhet në bazë të procedurës PRD-02, Rishikimi 1 datë 18.07.2019. Ky proces parashikohet të kryhet 1 herë në vit. Është planifikuar se mbledhja e drejtimi do të bëhet në mes të muajit Dhjetor sipas proçedurës përkatëse.

\section{\begin{tabular}{l|l}
5.8 .1 & Të përgjithshme
\end{tabular}}

Është në përputhje me standardin dhe të dhënat mbahen në bazë të normës.

\begin{tabular}{|l|l|}
\hline 5.8 .2 & Elemente në hyrje për rishqyrtimin \\
\hline
\end{tabular}


Në përputhje me procedurën e përcaktuar u shqyrtuan të gjithë elementet në hyrje.

\section{\begin{tabular}{l|l}
5.8 .3 & Elemente në dalje të rishqyrtimit
\end{tabular}}

Pas rishqyrtimit të menaxhmentit u morën vendime në lidhje me përmirësimin e sistemit.

\section{P6. Menaxhimi i burimeve}

\begin{tabular}{|l|l|l|l|l|l|}
\hline Paragrafi & & Zona/Argumenti & NA & K & JK \\
\hline 6.1 & Vënia në dispozicion të burimeve & Cilësia & & $X$ & \\
\hline
\end{tabular}

Ekziston në kompani dokumentacioni i lidhur me formimin e stafit. Procedura përkatëse është

PRD-06 Rishikimi 1 datë 18.07.2019.

\begin{tabular}{|l|l|l|l|l|l|}
\hline Paragrafi & & Zona/Argumenti & NA & K & JK \\
\hline 6.2 & Burimet njerëzore & Cilësia & & $X$ & \\
\hline
\end{tabular}

Përsa i përket burimeve njerëzore ekzistojnë skedat e personelit, të cilat japin të dhëna të mjaftueshme për secilin punonjës.

Është parë skeda e punonjësit Bahtir Gashi, i cili mban Pozicionin e Menaxherit të Cilësisë dhe Sigurisë Ushqimore. Ai ka kryer trajnim mbi ISO 22000 më datë 25.07.2019.

Personat të cilët kanë kryer trajnimet janë të pajisur me çertifikatat përkatëse.

\subsection{1 $\quad$ Të përgjithshme}

Të gjitha modalitetet janë të përcaktuara sipas procedurës PRD-06 Rishikimi 2, Datë 02.05.2019.

\section{\begin{tabular}{l|l}
6.2 .2 & Kompetenca, ndërgjegjësimi dhe trajnimi
\end{tabular}}

Deri më sot janë formalizuar gjithë dokumentet të lidhura me Menaxhimin e Burimeve. Janë mbajtur kurse të formimit, të cilat janë regjistruar në skedat e personelit PRD-06-MOD-01,

Rishikimi 3 datë 03.04.2019. Gjithashtu ekzistojnë profile të punës, në të cilat shfaqen kompetencat për secilin pozicion dhe përfshirja e tyre në proçeset dhe objektivat e ndërmarra nga kompania. Identifikimi dhe planifikimi i nevojave për trajnim ndiqet nga Menaxheri i Burimeve Njerëzore, i cili i regjistron trajnimet në raporte të veçanta.

U pa raporti i trajnimit mbi ISO 22000 i zhvilluar më datë 25.07.2019.

\begin{tabular}{|l|l|l|l|l|l|}
\hline Paragrafi & & Zona/Argumenti & NA & K & JK \\
\hline 6.3 & Infrastruktura & Cilësia & & X & \\
\hline
\end{tabular}

Kompania ka përcaktuar dhe mirëmban infrastrukturat e nevojshme për të siguruar konformitetin e produktit.

\begin{tabular}{|l|l|l|l|l|}
\hline Paragrafi & & Zona/Argumenti & NA & C \\
\hline 6.4 & Ambienti i punës & Cilësia & & X \\
\hline
\end{tabular}

Mjediset e punës janë të pajisura me të gjitha mjetet e nevojshme që ndihmojnë në proçeset e punës duke lehtësuar pastrimet dhe sanifikimet dhe penguar kontaminimet e kryqëzuara. Çdo punonjësi i janë krijuar 
kushtet e përshtatshme për të realizuar në mënyre më efektive të mundshme proçesin e tij të punës dhe janë ndërgjegjësuar dhe aftësuar ndaj parimeve të sigurisë ushqimore.

\section{P7.}

\section{Paragrafi}

7.1

Planifikimi dhe realizmi i produktit te sigurtë

\begin{tabular}{|l|l|l|l|l|}
\hline & Zona/Argumenti & NA & K & JK \\
\hline Kërkesa të përgjithshme & & & X & \\
\hline
\end{tabular}

axhmenti i Lartë ka ndërtuar procedurën e procesit të planifikimit dhe realizimit të produktit të sigurtë, e cila është formalizuar në dokumentin e kodifikuar PRD-07, Rishikimi 3 datë 03.04.2019. I gjithë procesi është i dokumentuar sipas formularëve përkatës që janë përcaktuar në procedurën e mësipërme.

\begin{tabular}{|c|c|c|c|c|c|}
\hline Paragrafi & & Zona/Argumenti & NA & $\mathbf{K}$ & JK \\
\hline 7.2 & $\begin{array}{l}\text { Programet e Masave Parandaluese } \\
\text { (PMP ose PRP) }\end{array}$ & & & $\mathrm{X}$ & \\
\hline
\end{tabular}

Kompania ka krijuar dhe mirëmbajtur Programin e Masave Parandaluese, të cilat janë të aprovuara nga Grupi i Sigurisë Ushqimore.

\begin{tabular}{|l|l|l|l|l|l|}
\hline Paragrafi & Zona/Argumenti & NA & K & JK \\
\hline 7.3 & $\begin{array}{l}\text { Hapat paraprake për analizën e } \\
\text { rreziqeve }\end{array}$ & & $\mathrm{X}$ & \\
\hline
\end{tabular}

\section{\begin{tabular}{l|l}
\hline 7.3 .1 & Të përgjithshme
\end{tabular}}

Kompania merr informacione të nevojshme në lidhje me analizat e rrezikut.

7.3.2

\section{Grupi i Sigurisë Ushqimore}

Administratori emëron Grupin e Sigurisë Ushqimore për të zhvilluar Sistemin e Manaxhimit të Sigurisë Ushqimore. Ekzistojnë regjistrime që demostrojnë kompetencat e përbërësve të grupit.

\section{\begin{tabular}{l|l} 
7.3.3 & Karakteristikat e produktit \\
\hline
\end{tabular}}

\section{\begin{tabular}{l|l} 
7.3.3.1 & Lëndët e para, përbërësit dhe materialet në kontakt me produktin
\end{tabular}}

Ekziston dokumentacioni për lëndët e para dhe përbërësit e produkteve, për të arritur ndjekjen e analizave të rrezikut.

\section{\begin{tabular}{l|l} 
7.3.3.2 & Karakteristikat e produktit përfundimtar
\end{tabular}}

Ekziston dokumentacioni për produktet përfundimtare për të arritur ndjekjen e analizave të rrezikut.

\section{\begin{tabular}{l|l} 
7.3.4 & Qëllimi i përdorimit
\end{tabular}}

Ekziston dokumentacioni për manipulimin dhe përdorimin e produkteve përfundimtare për të ndjekur analizën e rrezikut.

\section{\begin{tabular}{l|l} 
7.3.5 & Diagrama e fluksit, hapat e proçesit dhe matjet e kontrollit
\end{tabular}}


Ekziston dokumentacioni lidhur me diagramat e fluksit, për të verifikuar dhe vlerësuar rreziqet e sigurisë ushqimore. Diagramat e fluksit janë të qarta, detajuara dhe të sakta. Grupi i Sigurisë Ushqimore ka verifikuar në vend saktësinë e diagramave.

\subsubsection{2 $\quad$ Përshkrimi i hapave të proçesit dhe matjeve të kontrollit}

Nga momenti që vjen lënda e parë bëhet kontroll vizual dhe laboratorik i tyre. Nëse produkti është konform kërkesës kalon në magazinë. Në të kundërt i bëhet kthim mbrapsht furnitorit. Me pas ato ndjekin etapat e cilesuara ne diagrame deri ne daljen e produktit perfundimtar.

\begin{tabular}{|l|l|l|l|l|l|}
\hline Paragrafi & & Zona/Argumenti & NA & K & JK \\
\hline 7.4 & Analiza e rreziqeve & & & & \\
\hline
\end{tabular}

Janë ruajtur regjistrimet e diagramave të fluksit dhe ekzistojnë dokumenta të cilat paraqesin matjen e kontrollit për analizat e rrezikut.

\section{\begin{tabular}{l|l} 
7.4.1 & Të përgjithshme
\end{tabular}}

Analizat e rreziqeve ushqimore ndërmerren nga Grupi i Sigurisë Ushqimore. Ato përcaktojnë nëse janë të nevojshme veprimet parandaluese.

\section{\begin{tabular}{l|l}
7.4 .2 & Identifikimi i rreziqeve dhe përcaktimi i nivelit të pranueshëm
\end{tabular}}

Janë identifikuar dhe regjistruar rreziqet për Sigurinë Ushqimore në lidhje me tipin e produktit, tipin e proçesit dhe me strukturën e përpunimit. Gjithashtu janë identifikuar fazat në të cilat mund të ketë ndërhyrje. Për çdo rrezik është përcaktuar një nivel i pranueshëm për Sigurinë Ushqimore.

\section{\begin{tabular}{l|l}
7.4 .3 & Vlerësimi i rreziqeve \\
\hline
\end{tabular}}

Është bërë një vlerësim i rrezikut të identifikuar për të përcaktuar nëse mund të reduktohet apo eleminohet rreziku në prodhimin e një produkti të sigurtë ushqimor.

\section{\begin{tabular}{l|l}
7.4 .4 & Zgjedhja dhe vlerësimi i matjeve të kontrollit
\end{tabular}}

Matjet e kontrollit të kryera nga kompania sjellin parandalimin, eleminimin dhe reduktimin e rreziqeve për Sigurinë Ushqimore. Grupi i Sigurisë Ushqimore i kategorizon matjet e kontrollot si Programe të Masave Parandaluese ose si të Planit HACCP. Ekzistojnë regjistrime të përshtatshme për matjen e parametrave të proçeseve.

\begin{tabular}{|l|l|l|l|l|l|}
\hline & & Zona/Argumenti & NA & K & JK \\
\hline 7.5 & $\begin{array}{l}\text { Zhvillimi i programeve të kushteve } \\
\text { paraprake (PRP) }\end{array}$ & & $\mathrm{X}$ & \\
\hline
\end{tabular}

Ekzistojnë dokumente dhe regjistrime të lidhura me PMP operative.

\begin{tabular}{|l|l|l|l|l|l|}
\hline & & Zona/Argumenti & NA & K & JK \\
\hline 7.6 & Vendosja e Planit HACCP & & & X & \\
\hline
\end{tabular}

Ekziston plani i HACCP për produktet e kompanisë.

\begin{tabular}{|l|l}
\hline 7.6 .1 & Plani HACCP \\
\hline
\end{tabular}


Çdo pikë kritike kontrolli (PKK) e Planit HACCP ka identifikuar kërkesat thelbësore sipas normës ISO 22000:2005.

\section{\begin{tabular}{l|l} 
7.6.2 & Identifikimi i pikave kritike të kontrollit (CCPs) \\
\hline
\end{tabular}}

Janë identifikuar pikat kritike të kontrollit për çdo rrezik të kontrolluar nga Plani HACCP.

\section{\begin{tabular}{l|l}
7.6 .3 & Përcaktimi i limitit kritik të pikave kritike të kontrollit
\end{tabular}}

Për çdo pikë kritike janë përcaktuar limite kritike. Limitet kritike të përcaktuara sigurojnë që niveli i pranueshëm i rrezikut të produktit të përfunduar nuk është tejkaluar. Limitet kritike janë të matshme. Është e dokumentuar zgjedhja e limiteve kritike.

\section{\begin{tabular}{l|l}
7.6 .4 & Sistemi i monitorimit të pikave kritike të kontrollit
\end{tabular}}

Ekzistojnë procedura, instruksione dhe regjistrime për sistemin e monitorimit. Është përcaktuar një sistem i monitorimit për çdo PKK, i cili tregon në është nën kontroll apo jo. Metodat dhe shpeshtësia e monitorimit janë në gjendje të përcaktojnë tejkalimin e limiteve kritike për të izoluar produktin përfundimtar.

\section{\begin{tabular}{l|l} 
7.6.5 & Veprimet e ndërmarra kur tejkalohen limiti kritik
\end{tabular}}

Ekziston një procedurë e dokumentuar për manaxhimin e produkteve jo të sigurta. Plani HACCP specifikon veprimet korigjuese të ndërmarra kur tejkalohen limitet kritike. Të njëjtat veprime sigurojnë identifikimin e shkakut të jo konformitetit dhe veprimet për të evituar një verifikim të ri.

\begin{tabular}{|l|l|l|l|l|l|}
\hline Paragrafi & & Zona/Argumenti & NA & K & JK \\
\hline 7.7 & $\begin{array}{l}\text { Përditësimi i informacionit dhe } \\
\text { dokumentacionit praraprak të } \\
\text { PRPs dhe planit HACCP }\end{array}$ & & X & \\
\hline
\end{tabular}

Kompania ka parashikuar përditësimin dhe modifikimin e dokumentacionit paraprak të PRPs dhe planit HACCP.

\begin{tabular}{|l|l|l|l|l|l|}
\hline Paragrafi & & Zona/Argumenti & NA & K & JK \\
\hline 7.8 & Planifikimi i verifikimit & & & $X$ & \\
\hline
\end{tabular}

Planifikimi i verifikimit përcakton qëllimin, metodat dhe shpeshtësinë e përgjegjësisë. Ekzistojnë regjistrime të verifikimit dhe komunikacionit me Grupin e Sigurisë Ushqimore. Verifikimi konfirmon treguesit që vijnë nga norma ISO 22000:2005.

\begin{tabular}{|l|l|l|l|l|l|}
\hline Paragrafi & & Zona/Argumenti & NA & K & JK \\
\hline 7.9 & Sistemi i gjurmueshmërisë & & & $X$ & \\
\hline
\end{tabular}

Është parashikuar një sistem gjurmimi për të identifikuar lotet e produktit me lëndën e parë, proceset dhe shpërndarjet e produktit. Sistemi i gjurmueshmërisë konsiston në identifikimin e materialeve në përdorim dhe ecurinë e shpërndarjes fillestare të produktit final. 
Janë mbajtur regjistrimet e gjurmueshmërisë për një rrezik të till, për të qënë në gjendje të manaxhohen produktet jo të sigurta dhe tërheqjet e tyre.

\begin{tabular}{|l|l|l|l|l|l|}
\hline Paragrafi & & Zona/Argumenti & NA & K & JK \\
\hline 7.10 & Kontrolli i moskonformiteteve & & & $X$ & \\
\hline
\end{tabular}

Të gjitha jokonformitetet regjistrohen në formularin përkatës PRD-03-MOD-01, Rregjistri i jokonformiteteve.

Është parë regjistri i jokonformiteteve, i cili nuk kishte pasqyruar asnjë jokonformitet.

Jokonformitet më pas pasqyrohen edhe në formularin PRD-03-MOD-02, Raporti i jokonformiteteve, ku bëhet edhe një analizë e mos-konformiteti.

\section{\begin{tabular}{l|l}
7.10 .1 & Korrigjimet
\end{tabular}}

Ekziston një procedurë e dokumentuar për veprimet korigjuese. Janë mbajtur dhe regjistruar të gjitha moskonformitetet e ndodhura.

\section{\begin{tabular}{l|l}
7.10 .2 & Veprimet korrigjuese
\end{tabular}}

Ekziston një procedurë e dokumentuar për veprimet korigjuese. Të gjitha veprimet korrigjuese janë të dokumentuara në formularin përkatës PRD-03-MOD-03.

\section{\begin{tabular}{|l|l}
7.10 .3 & Trajtimet e produkteve të pasigurta \\
\hline
\end{tabular}}

\section{\begin{tabular}{l|l} 
7.10.3.1 & Të përgjithshme
\end{tabular}}

Ekzistojnë regjistrime të menaxhimit të produkteve jo konform.

\begin{tabular}{|l|l|}
\hline 7.10 .3 .2 & Vlerësimi i produkteve të lëshuara \\
\hline
\end{tabular}

\section{\begin{tabular}{l|l} 
7.10.3.3 & Natyra e produkteve me moskonformitet
\end{tabular}}

Natyra e produkteve me mos konformitet dallohet tek ngjyra e produktit, lagështia dhe vyshkja.

\section{\begin{tabular}{l|l}
7.10 .4 & Tërheqjet
\end{tabular}}

Ekziston një procedurë e dokumentuar për të menaxhuar produktet dhe veprimet që ndërmerren. Ekzistojnë regjistrime lidhur me shkakun, përhapjen dhe rezultatin e tërheqjeve. Gjithashtu ekzistojnë regjistrime për verifikimin e efikasitetit të programit të tërheqjes.

Administratori ka emëruar persona përgjegjës për të ndjekur tërheqjet.

\section{P8. Matja, analiza dhepërmirësimi i sistemit të menaxhimit të sigurisë ushqimore}

\begin{tabular}{|l|l|l|l|l|l|}
\hline Paragrafi & Zona/Argumenti & NA & K & JK \\
\hline 8.1 & Të përgjithshme & Cilësia & & X & \\
\hline Grupi për Sigurinë Ushqimore ka planifikuar dhe caktuar të gjitha proceset e kryerjes së matjeve të \\
kontrollit. Matjet e kontrollit janë efikase.
\end{tabular}




\begin{tabular}{|l|l|l|l|l|l|}
\hline Paragrafi & & Zona/Argumenti & NA & K & JK \\
\hline 8.2 & $\begin{array}{l}\text { Vlerësimi dhe miratimi i matjeve të } \\
\text { kombinuara të kontrollit }\end{array}$ & Cilësia & & X & \\
\hline
\end{tabular}

Është parashikuar modifikimi i matjeve të kontrollit në varësi të rezultateve të vlerësimit ende të pakonfirmuara. Modifikimet përfshijnë ndryshimin e lëndës së parë, teknologji të përpunimit, karakteristika të produktit etj.

\begin{tabular}{|l|ll|l|l|l|l|}
\hline Paragrafi & & & Zona/Argumenti & NA & K & JK \\
\hline 8.3 & $\begin{array}{l}\text { Kontrolli i monitorimeve dhe } \\
\text { matjeve }\end{array}$ & Cilësia & & X & \\
\hline
\end{tabular}

Ekzistojnë regjistrime të kontrollit të pajisjeve të matjes, të cilat merren nën kontroll nga pajisjet e matjes.

\begin{tabular}{|l|l|l|l|l|l|}
\hline Paragrafi & Zona/Argumenti & NA & K & JK \\
\hline 8.4 & $\begin{array}{l}\text { Verifikimi i Sistemit të Manaxhimit } \\
\text { të Sigurisë Ushqimore }\end{array}$ & Cilësia & & X & \\
\hline
\end{tabular}

Ekziston një procedurë e dokumentuar lidhur me verifikimin e Sistemit të Menaxhimit të Sigurisë Ushqimore. Ekzistojnë regjistrime të vlerësimeve të rezultateve të verifikimit nga ana e Grupit të Sigurisë Ushqimore.

\section{\begin{tabular}{l|l} 
8.4.1 & Audit i brendshëm
\end{tabular}}

Realizohen në bazë të procedurës PRD-01 dhe formalizohen në raportin PRD-01-MOD-02,Rishikimi 3 datë 03.04.2019. Këto regjistrime janë konform normës ISO 22000:2005 dhe veprojnë në mënyrë efikase. Ato përditësohen sa herë që ndodh auditi i brendshëm.

\section{\begin{tabular}{l|l}
8.4 .2 & Vlerësimi i verifikimeve individuale të të dhënave
\end{tabular}}

Ekzistojnë regjistrime të veprimeve të ndërmarra për të ndjekur rastet e moskonformitetit të dalë nga verifikimi.

\section{\begin{tabular}{l|l}
8.4 .3 & Analiza e të dhënave nga verifikimi i aktiviteteve
\end{tabular}}

Analiza e të dhënave nga verifikimi i aktiviteteve bazohet në verifikim e auditit të brendshëm.

\begin{tabular}{|l|l|l|l|l|l|}
\hline Paragrafi & & Zona/Argumenti & NA & K & JK \\
\hline 8.5 & Përmirësimi & Cilesia & & X & \\
\hline
\end{tabular}

Kompania ka parashikuar veprime dhe regjistrime të ndërmarra për përmirësimin e Sistemit të Manaxhimit të Sigurisë Ushqimore.

\begin{tabular}{|l|l|}
\hline 8.5 .1 & Përmirësimi i vazhdueshëm \\
\hline Përmirësimi i vazhdueshëm është parashikuar të realizohet me anë të procedurave të jokonformitetit. \\
\hline 8.5 .2 & Përditësimi i sistemit të menaxhimit të sigurisë ushqimore \\
\hline
\end{tabular}


Grupi i Sigurisë Ushqimore ka planifikuar përditësimin e e Sistemit të Menaxhimit të Sigurisë Ushqimore.

\section{Konklusioni dhe komente shtesë :}

Dokumentacioni rezulton të jetë konform me kërkesat referuese të standardit ISO 22000:2005.

Aplikimi në proces është i mjaftueshëm dhe i kënaqshëm.

\section{Ruajtja}

Për shkak të llojit të punës së kryer, grupi i verifikimit mund të njihet me informacione të rezervuara. Asnjë nga këto informacione nuk do të shpërndahet nëse nuk egziston një autorizim me shkrim nga ana e kompanisë. 


\section{PREZANTIMI DHE ANALIZA E REZULTATEVE}

Ekipi i auditimit beson se sistemi i menaxhimit të sigurisë së ushqimit është adekuat për kompaninë. Personeli i intervistuar theksoi një shkallë kompetence dhe njohuri për rreziqet e sigurisë së duhur të ushqimit dhe një vetëdije të mirë të kërkesave dhe rregullave të sistemit të menaxhimit dhe vetëkontrollit.

Gjatë auditimit, kërkesat e standardit u verifikuan, siç raportohet në planin e auditimit. Kompania ka zhvilluar Sistemin e Menaxhimit të Sigurisë Ushqimore duke ia besuar këtë detyrë grupit punues të HACCP.

Kompania menaxhon dhe kontrollon rreziqet e identifikuara përmes identifikimin dhe zbatimin e masave adekuate të kontrollit për PKK të përgjithshme / operative dhe PKK të identifikuara dhe të menaxhuara në planin e vetëkontrollit dhe pjesërisht me procedura të brendshme.

1-Higjena e personelit: veshja është e përshtatshme dhe adekuate për këtë lemi gjithashtu dezinfektimi i duarve dhe këmbeve është në bazë te standardeve

2-Programi i trajnimi: kontrolli shëndetësor dhe higjenik i personelit; stafi është i vëmendshëm ndaj praktikave të mira të higjienës;

3- Asgjësimi i mbeturinave: Kompania ka kontratë me komunen për largimin e mbeturinave të cilat formohen gjatë procesit të përpunimit të produkteve

4- Furnizimi me ujë: Protokolli analitik parashikon kontrollin mikrobiologjik gjashtëmujor të ujit të pijshëm, nga Institute Kombëtar i Shëndetësisë Publike të Kosovës IKSHPK

5-Kontrolli i dëmtimeve (DDD): Kompania ka një kontratë me kompaninë Fauna e cila është e specializuar për ushtrimin e kësaj veprimtarie.

6- Higjiena e mjedisit: procedura dhe pastrimit kimik, objekti është në kushte të mira higjienike dhe janë vendosur procedura të higjienës si larja dhe dezinfektimi i duarve dhe shputës së këpucëve përpara se të hyjnë në prodhim. Veshje të përshtatshme për hyrjen e personave që nuk janë të përfshirë në punë. Plani i pastrimit është me specifikimin e llojit të pajisjeve, frekuencës, metodës së pastrimit kimik, dhe përgjegjësit. Një listë e detergjenteve komerciale dhe kimike është në dispozicion, egziston lista e vizituar e 
detergjentve dhe dezinfektusve. Monitorimi i pastrimit regjistrohet në forma specifike dhe rregullisht plotësohet ne formularet e pastrimit.

\section{Kontrolli i lëndesë së pare:}

Kontrolli i lëndesë së parë bëhet në mënyrë të rregullt nga personi përegjegjës. Është bërë kontrolli i skedës së pranimit të lëndë së parë me Nr.28 -Mish Gjedhi - me numër të certifiakës të lëshuar nga Agjensioni i Ushqimit dhe Veterinarië Nr.00407/4334/18,ku janë të paraqitura të gjitha informacionet për lëndën e parë si:origjina, furnitori, data e prodhimit, data e skadimit, sasia e produktit, mjeti transportues, ndërsa në formularin e pranimit të lëndës së parë personi përgjegjës bën regjistrimin e të dhënave sic janë: analizat organo-leptike (shija, ngjyra, aroma), temperaturen e produktit, $\mathrm{pH}$ e produktit, higjienën e mjetit transportues, temperaturën e mjetit transportues.

\section{Kontrolli i produktit gjatë proceseve teknologjike}

Formulari i prodhimit me Lot 12/03

Kompania bënë monitorimin dhe përcjelljen e produktit nga lënda e parë në të gjitha proceset teknologjike deri tek produkti përfundimtar. Çdo produkt ka një formular prodhimi ku në të janë të shkruara të gjitha hapat që merren gjatë proceseve teknologjike për prodhimin e produkteve.

Në të janë të dhënat për lëndën e parë, aditivët, temperaturat e përpunimit, procesi i homogjenizimit, procesi i mbushjes, proceset termike, temperaturat e pasterizimit, koha e proceseve termike. Gjithashtu janë të regjistruar të dhënat për ambalazhimin dhe rujtjen e produktit, me një fjalë ky formular është kartë teknologjike për çdo produkt.

Kompania ka kontratë me Institutin Kombëtar i Shëndetësisë Publike të Kosovës-IKSHPK-së për analizat e ujit që përdoret si lëndë e parë nga kompania, gjithashtu dhe për analizat e produkteve përfundimtare.Është bërë kontrolli i analizës së ujit me Nr.LUSH-2-4983 nga Instituti Kombëtar i Shëndetësisë Publike të Kosovës-IKSHPK-së ku janë të paraqitura rezultatet e analizave fizikokimike, dhe mikroobilogjike dhe metalet e rënda.Në bazë të analizave është vërtetuar se uji i cili përdoret nga kompania i plotëson të gjitha standardet që të futet si lëndë e parë në përpunimin e produkteve.Po ashtu është bër kontrolli i analizës së produktit përfundimtar PARIZIER PULE 400grme Lot:11 / 14 me numër të analizës Nr.LUSH 1,2-4974.Në bazë te analizave të paraqitura vërtetohet se produktet i plotësojnë të gjitha standardet për konsumim nga konsumatorët. 


\section{Konkluzione dhe rekomandime}

\subsection{Konkluzione}

Gjatë takimit, menaxhmentit i'u kujtua rëndësia e rezultateve të pritura nga një kompani me një sistem menaxhimi që posedon një certifikatë të akredituar. Auditimi u krye në bazë të një procesi të mostrimit të informacionit në dispozicion, duke verifikuar proceset / aspektet e përcaktuara nga kompania dhe kërkesat e standardit të referencës; mungesa e mundshme e gjetjeve nuk garanton mungesën totale të anomalive në zonat e verifikuara ose në zona të tjera.

Sipas mendimit të Ekipit të Auditimit, a është fusha e zbatimit të certifikimit adekuate?

A e rekomandon ekipi i auditimit kompanin për certifikim / ricertifikim apo e konfirmon vlefshmërinë e certifikimit?

Sipas mendimit të Ekipit të Auditimit, Sistemi i Menaxhimit në kompani, në tërësi, ishte efektiv dhe në përputhje me kërkesat e standardit dhe të Rregullores përkatëse të Çertifikimit Ekipi i auditimit e konsideron të përshtatshme të kryej auditimin e ardhshëm të mirëmbajtjes nga data ose brenda 12 muajve nga kjo vizitë .

\subsection{Rekomandime}

Paragrafi 5.5

Identifikimi më i mirë i ekipit dhe menaxherëve të krizës në tabelën e organizimit

Paragrafi 7.1

Futja e Lotit të prodhimit të ambalazhit në formularin e prodhimit

Paragrafi 7.1

Përmirësimi i menaxhimit të qeseve plastike të cilat janë të hapura gjatë përgatitjes së sallamit dhe mbulesave të karrelave që presin per përpunimin.

Paragrafi 7.9

Përmirësimi i ruajtjes së mostrave të produktit për çdo mall.

Paragrafi 8.1 
Identifikimi i masave parandaluese për brejtësit, zogjtë dhe insektet e paqëndrueshme, të vendosen më mirë në hartën e kompanisë.

\section{Referencat}

EN ISO 9001:2008 - Sistemet e Menaxhimit të Cilësisë - Kërkesat

EN ISO 22000:2005 - Menaxhimi i Sigurisë Ushqimore

EN ISO 19011:2012 - Udhëzues për kontrollin e sistemeve të menaxhimit tëcilësisë dhe mjedisit

EN ISO 9000:2005 - Sistemi i Menaxhimit - Baza dhe fjalori

EN ISO 9004:2009 - Sistemi i Menaxhimit të Cilësisë - Udhëzues për përmirësim të qëndrueshëm

1. Klaas ëenztel, Richard Jackson of Zimbabëe. "ISO 22000: Requirements for Food Safety Management Systems". Retrieved 28 February 2008.

2.Hiroshi, Ogaëa. "Sterilization and sanitation technologies in the latest food manufacture processes, Total food safety management by ISO 22000 "food safety management system"". Retrieved 28 February 2008.

3.Mijanović Markuš, Marina (May 2006). "ISOC 22000:2005 and HACCP" (PDF). Festival kvaliteta 2006. Asocijacija za kvalitet i standardizaciju Srbije. Retrieved 17 October 2010.

4.Prati, R; Deborah A. McIntyre (2004). "The neë ISO 22000 (final proposal) norm on food safety management". Ingredienti Alimentari. Chiriotti Editori Spa. 3 (4): 19-21.

5.Surak, John G. "Comparison of ISO 9001 and ISO 22000" (PDF). Retrieved 28 February 2008. 6.Faergemand, Jacob; Dorte Jespersen. "ISO 22000 to ensure integrity of food supply chain" (PDF). Retrieved 28 February 2008.

7.Frost, Roger. "ISO 22000 is first in family of food safety management system standards" (PDF). Retrieved 28 February 2008.

8.Goichiro, Yukaëa. "The points of ISO 22000". Retrieved 28 February 2008.

9.European Office of Crafts, Trades and Small and Medium-sized Enterprises for Standardisation (2004). "Normapme Food Group Position on TC 34 draft standard ISO22000" (PDF). Retrieved 28 February 2008. 